\title{
De theorie van Darwin, de wet van Wolff, de hypothese van Sapir-Whorf en het opleiden van artsen
}

Citation for published version (APA):

Heyligers, I. C. (2013). De theorie van Darwin, de wet van Wolff, de hypothese van Sapir-Whorf en het opleiden van artsen. Maastricht University. https://doi.org/10.26481/spe.20130614ih

Document status and date:

Published: 14/06/2013

DOI:

10.26481/spe.20130614ih

Document Version:

Publisher's PDF, also known as Version of record

\section{Please check the document version of this publication:}

- A submitted manuscript is the version of the article upon submission and before peer-review. There can be important differences between the submitted version and the official published version of record.

People interested in the research are advised to contact the author for the final version of the publication, or visit the DOI to the publisher's website.

- The final author version and the galley proof are versions of the publication after peer review.

- The final published version features the final layout of the paper including the volume, issue and page numbers.

Link to publication

\footnotetext{
General rights rights.

- You may freely distribute the URL identifying the publication in the public portal. please follow below link for the End User Agreement:

www.umlib.nl/taverne-license

Take down policy

If you believe that this document breaches copyright please contact us at:

repository@maastrichtuniversity.nl

providing details and we will investigate your claim.
}

Copyright and moral rights for the publications made accessible in the public portal are retained by the authors and/or other copyright owners and it is a condition of accessing publications that users recognise and abide by the legal requirements associated with these

- Users may download and print one copy of any publication from the public portal for the purpose of private study or research.

- You may not further distribute the material or use it for any profit-making activity or commercial gain

If the publication is distributed under the terms of Article $25 \mathrm{fa}$ of the Dutch Copyright Act, indicated by the "Taverne" license above, 


\section{Maastricht University}

Oratie

Prof. dr. I de C. Heyligers

Faculty of Health, Medicine and Life Sciences

De theorie van Darwin, de wet van Wolff, de hypothese van Sapir-Whorf en het opleiden van artsen 
ORATIE

De theorie van Darwin, de wet van Wolff, de hypothese van Sapir-Whorf en het opleiden van artsen.

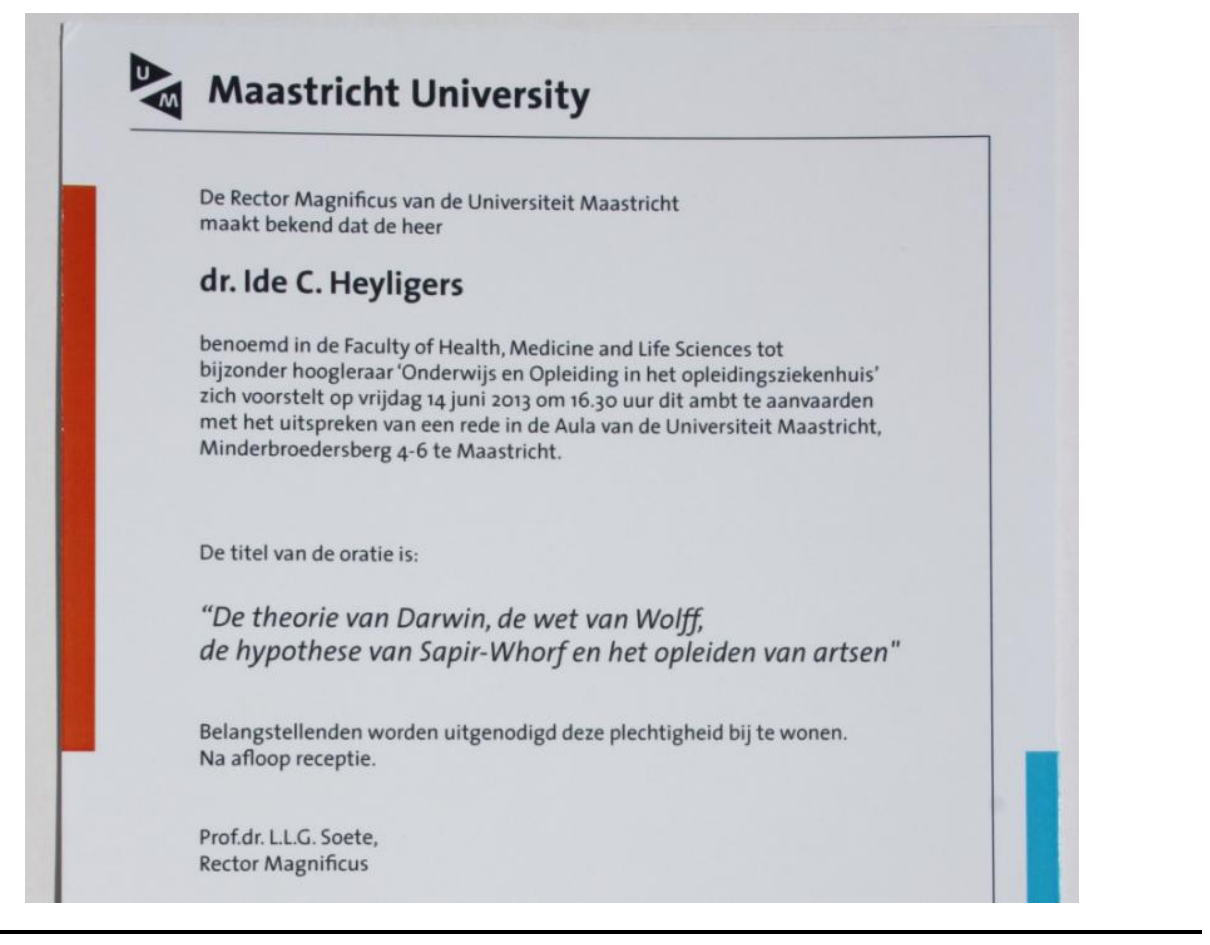

Mijnheer de Rector Magnificus, Leden van het College van Bestuur van de Universiteit van Maastricht, Leden van de Raad van Bestuur van het Maastricht Universitair Medisch Centrum, Leden van het College van Toezicht, Leden van de Raad van Bestuur van het Atrium Medisch Centrum, Hooggeleerde dames en heren, studenten, assistenten, collega's, familie, vrienden en andere belangstellenden, ik dank $U$ voor Uw komst naar het zwoele zuiden, voor sommigen na een lange reis.

"Heel langzaam nam het ongeloof bezit van mij, maar het deed dit tenslotte geheel". 
Charles Darwin

$1809-1882$

Adaptatie:

Aanpassing aan

de omgeving

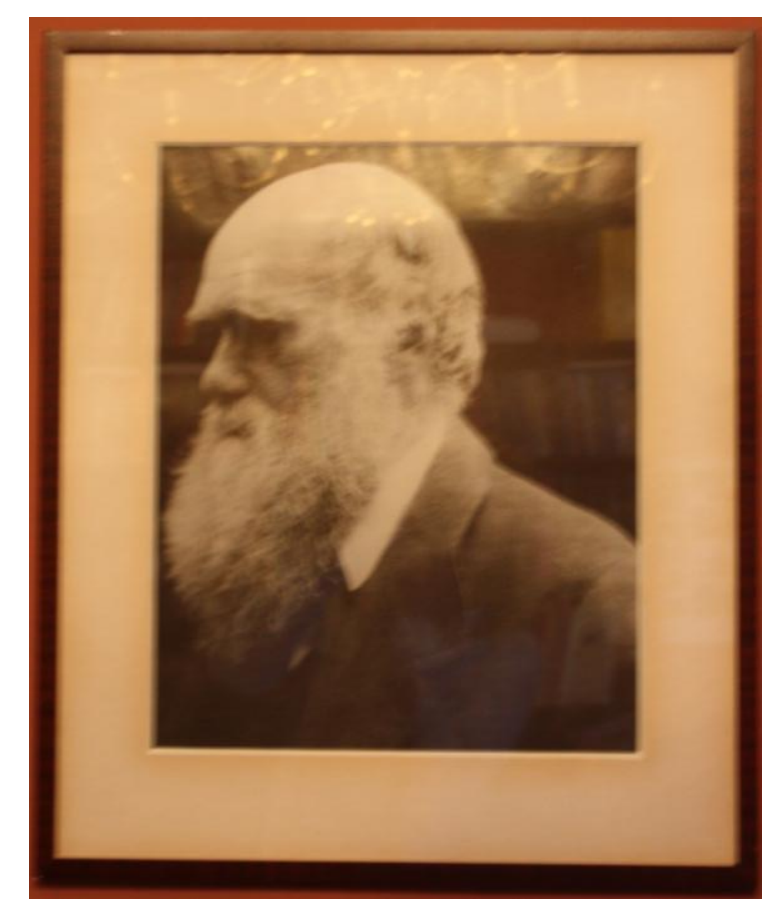

Dit schreef Charles Darwin in zijn autobiografie. "Ik heb sedert dien nimmer getwijfeld dat mijn gevolgtrekking juist was, dat elke soort zich op een gunstige manier aanpast aan zijn omgeving".

Al in 1837, een jaar na terugkeer van de reis met de Beagle, was Darwin in zijn eerste notitieboek begonnen over de transformatie van soorten. Hij was er zo zeer van overtuigd dat hij een belangrijk idee had dat hij een eerste schets van zijn theorie in een brief aan zijn vrouw stuurde met het verzoek dit wereldkundig te maken als hij plotseling mocht komen te overlijden. Na twee voorlopige versies zou het ruim 20 jaar duren voordat Darwin in 1859 zijn theorie publiceerde in het boek "On the Origin of Species by Means of Natural Selection".

Charles Darwin was een zeer wijs mens. Zo schreef hij ook: "Schoonheid is soms van groter betekenis dan succes in het gevecht". Wij kunnen veel van hem leren: hoe belangrijk het is om open te staan voor waarnemingen ook als deze volstrekt in tegenspraak zijn met de geldende norm, hoe belangrijk het is om een goed theoretisch kader te scheppen, hoe belangrijk het is om een goede echtgenote te hebben om een geheim te delen, het belang van schoonheid, maar natuurlijk vooral het begrip 'adaptatie' het feit dat de natuur zich optimaal aanpast aan de omstandigheden en deze aanpassing door geeft aan volgende generaties. De omgeving is dus van grote invloed. 


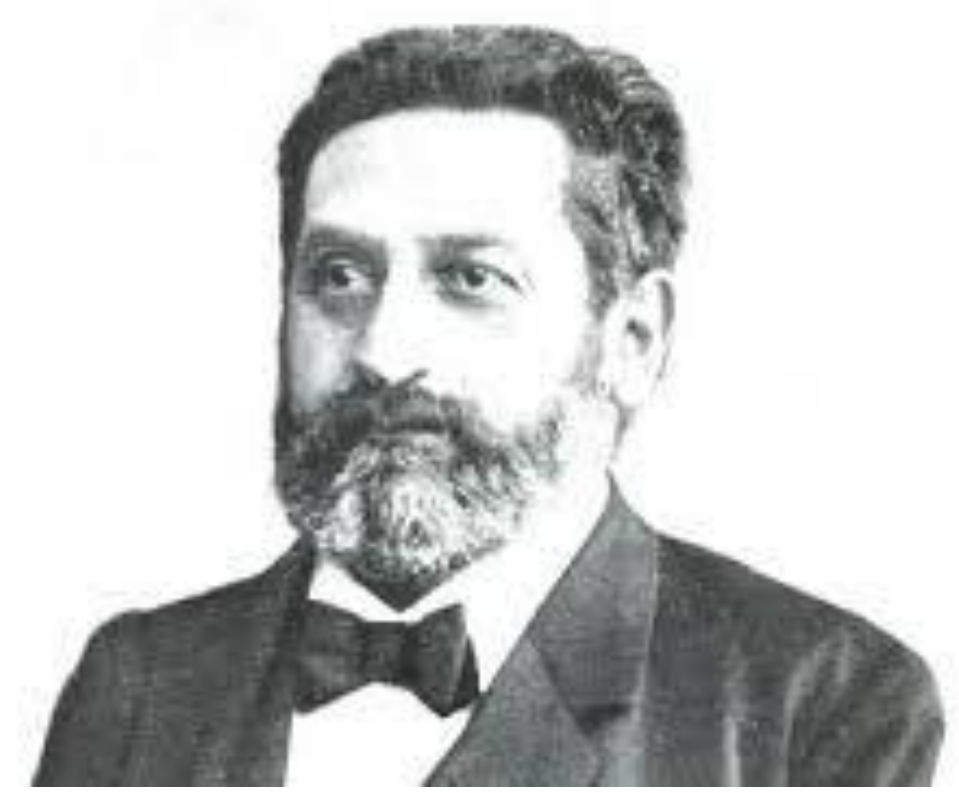

Julius Wolff 1836 - 1902

Architectuur bot gestuurd door belasting

Julius Wolff was een tijdgenoot van Darwin, een Duits anatoom en chirurg. Hij ontwikkelde de Wet van Wolff die stelt dat gezonde botten zich aanpassen aan de belasting waaraan zij worden blootgesteld. Hoe zwaarder de belasting hoe sterker het bot, hoe lichter de belasting hoe zwakker het bot.
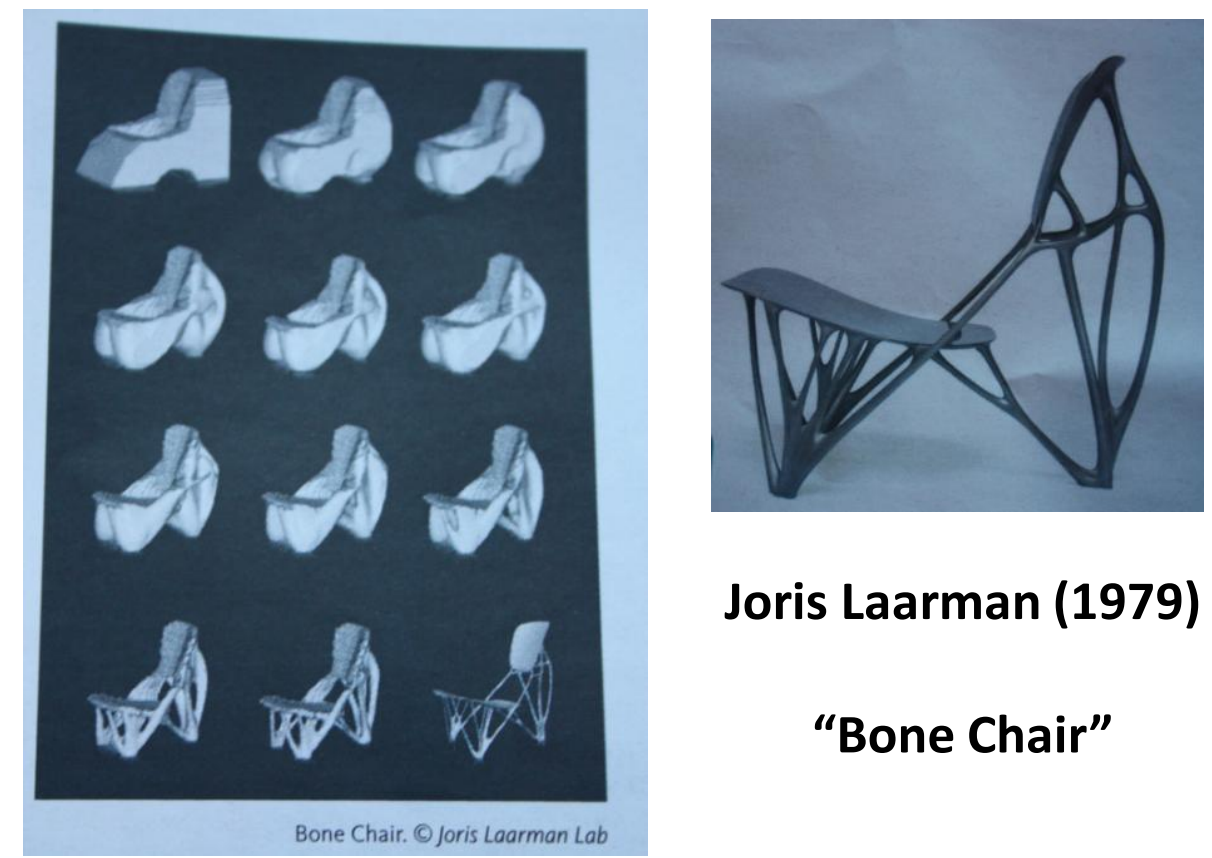

Joris Laarman (1979)

"Bone Chair" 
Ter illustratie ziet $\mathrm{U}$ hier een stoel die is ontworpen door Joris Laarman met behulp van de Wet van Wolff; de richting en dikte van de onderdelen wordt via een ingenieus computerprogramma bepaald door de belasting.

Als orthopaedisch chirurg maak ik dagelijks gebruik van de Wet van Wolff, in feite doen wij niet meer dan het faciliteren van de biologie. Zonder levende natuur is geen enkele operatie succesvol. Ik laat $U$ twee voorbeelden zien.

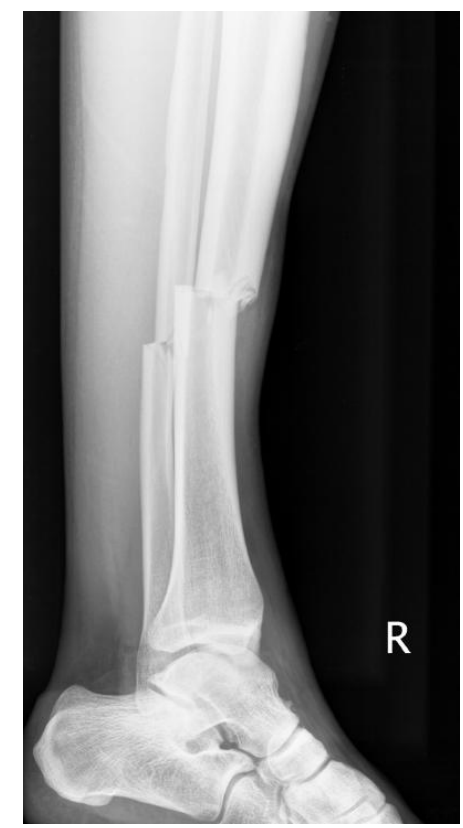

Breuk onderbeen

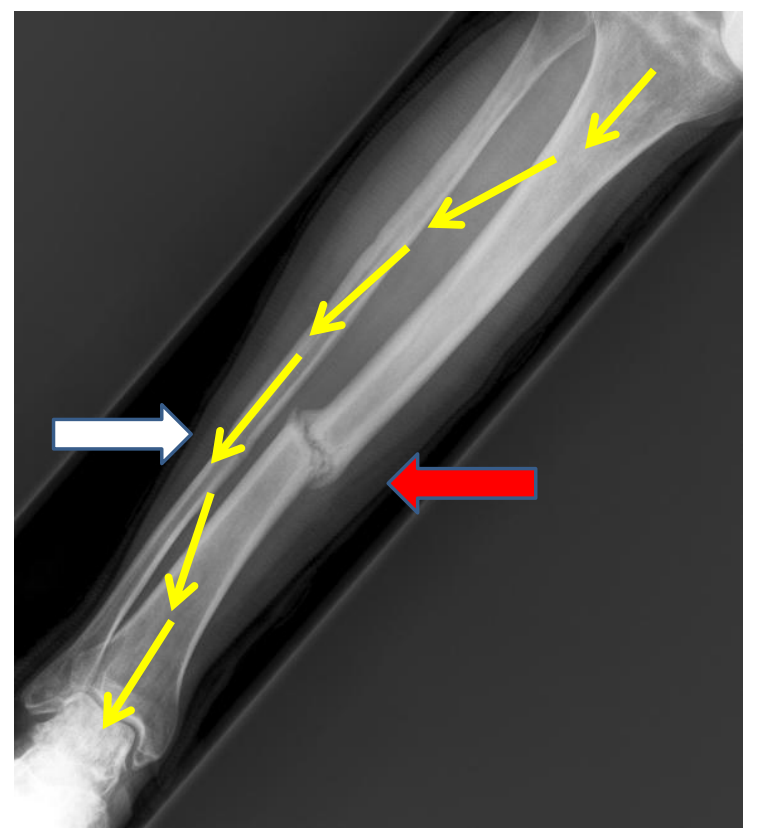

Gips, 6 maanden later

$U$ ziet hier een gebroken onderbeen. De belasting heeft hier duidelijk de belastbaarheid overschreden. De breuk werd behandeld met gips. Het dikkere scheenbeen is echter niet vastgegroeid; de rode pijl, het dunnere kuitbeen wel; de witte pijl. Dit kuitbeen voorkomt nu dat belasting van het scheenbeen ontstaat; de krachtlijnen gaan via het kuitbeen; de gele pijlen. 


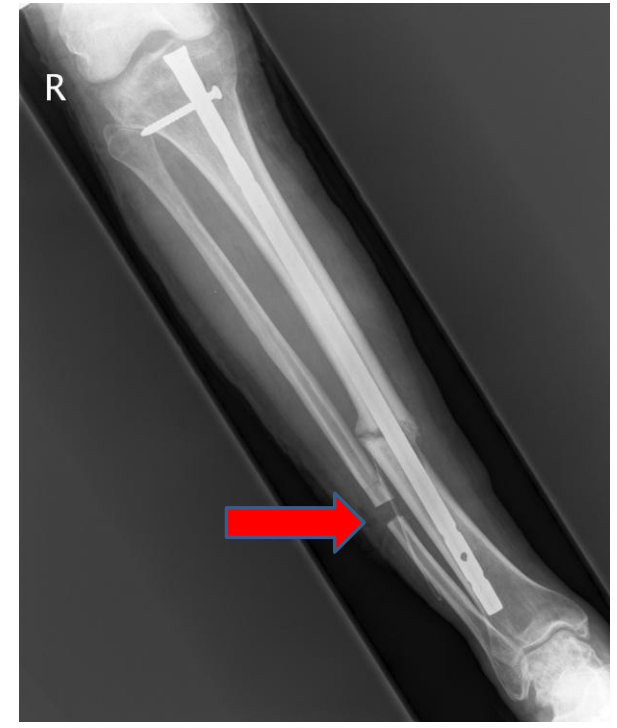

Stuk uit kuitbeen Pen in scheenbeen

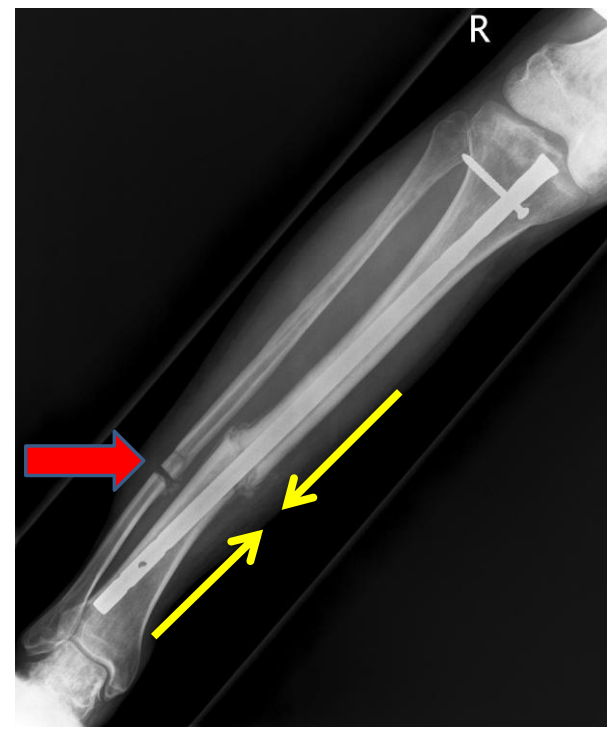

Na 6 weken scheenbeen vast

Door nu een gedeelte van het kuitbeen te verwijderen ontstaat er wel belasting op de breukplaats van het scheenbeen, waarin een pen is geplaatst. Nu groeit deze wel vast, geheel in overeenstemming met de Wet van Wolff. Voor de volledige belasting van het onderbeen kan men overigens wel het kuitbeen missen (dat wordt door ons ook wel eens gebruikt op een andere plaats), maar niet het scheenbeen, vandaar deze oplossing. 

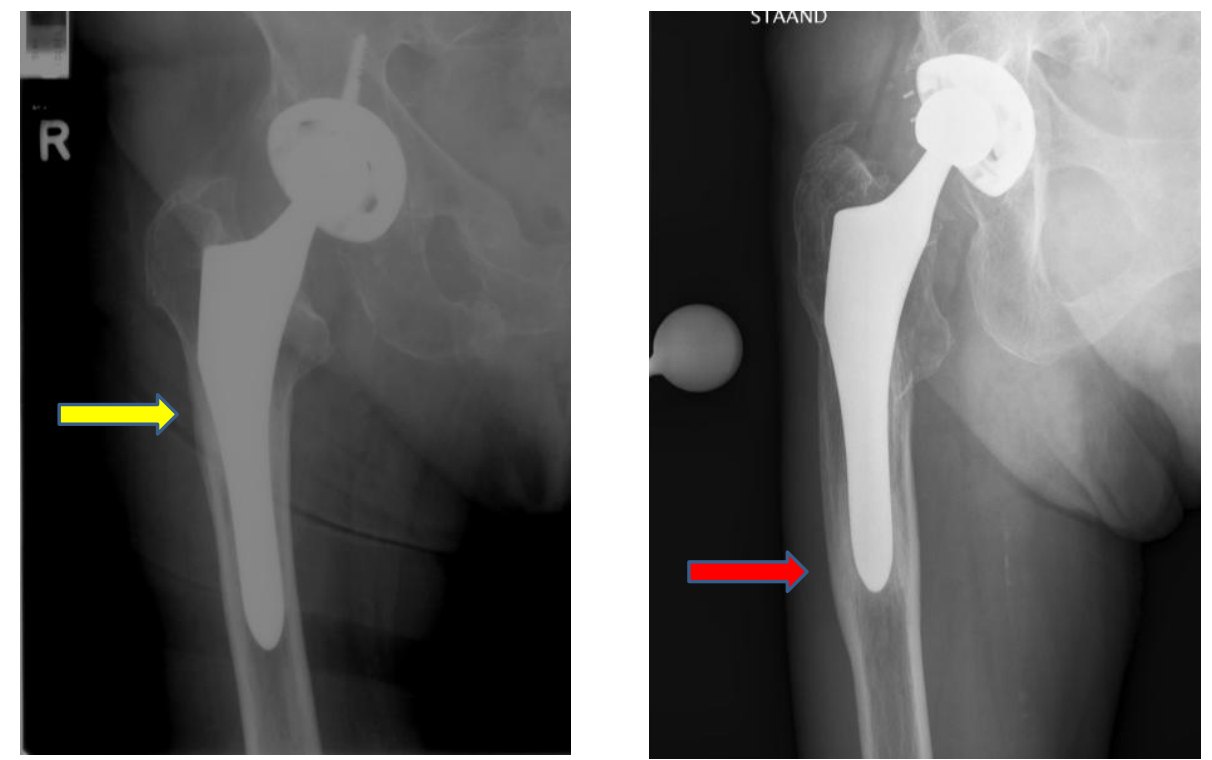

\section{Belasting, via heup steel, van bot $>$ dikker}

Hier een ander voorbeeld van de Wet van Wolff: twee röntgenfoto's van twee verschillende kunstheupen die al enkele jaren geleden in het dijbeenbot werden geplaatst. Links is de fixatie vooral in het bovenste deel van het dijbeen, bij de gele pijl, hier is het bot dan ook nog dik omdat voornamelijk daar de belasting plaats vindt. Rechts is de fixatie meer aan de onderzijde van de steel, bij de rode pijl. Wij zien dan ook dat het gedeelte van het bot dat hier wordt belast dikker is en dat het bot daarboven, dat afgeschermd wordt voor belasting resorbeert en dus veel dunner is. Over de fixatie van kunstheupen met en zonder cement en de remodellering van het bot kan ik nog uren praten, maar dat zal ik niet doen, vreest niet.

Wij zien dat het bot breekt als de belasting de belastbaarheid overschrijdt, sterker wordt als het juist wordt belast en zwakker als er geen of onvoldoende belasting is. Exact ditzelfde mechanisme speelt een rol bij de opleiding van artsen; zij kunnen breken door overbelasting, worden sterker als zij op de juiste manier worden belast en ontwikkelen zich onvoldoende bij te weinig belasting. De kunst van het opleiden is het doceren van deze belasting, het faciliteren van dit proces. Vele factoren spelen hierbij een belangrijke rol, één van de belangrijkste is communicatie. 


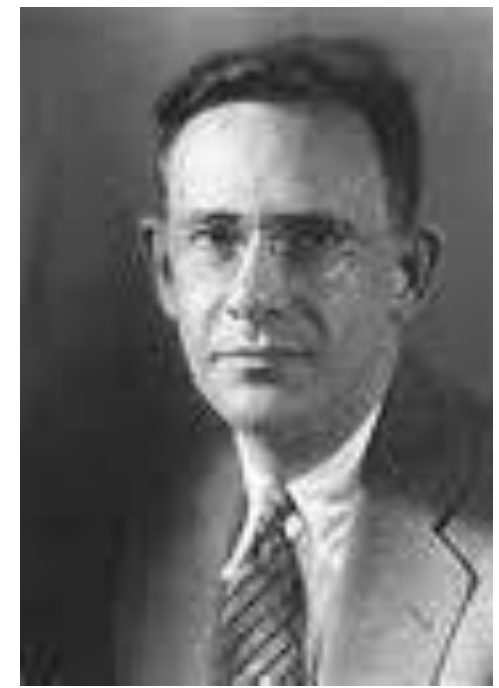

Edward Sapir 1884 - 1939

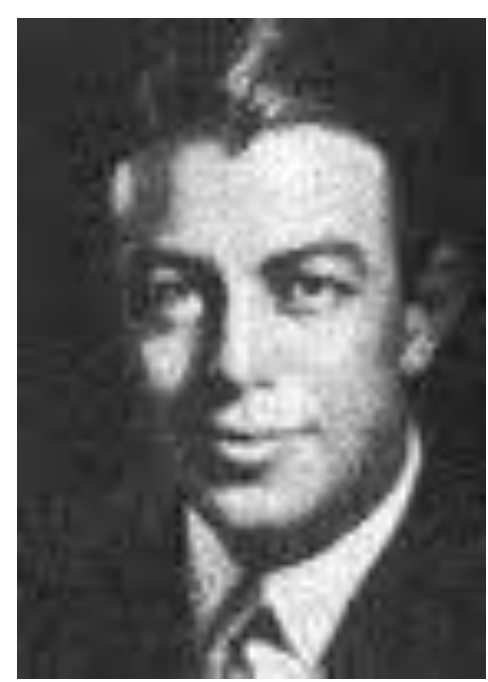

Benjamin Lee Whorf 1897 - 1941

Edward Sapir, was taalgeleerde en antropoloog. Zijn ideeën zijn uitgewerkt door zijn student Benjamin Lee Whorf, een specialist in de taal van de Hopi Indianen. Men spreekt van de Sapir-Whorf hypothese die claimt dat het gebruik van verschillende talen resulteert in een verschillende kijk op de wereld, in het beleven van een verschillende werkelijkheid.

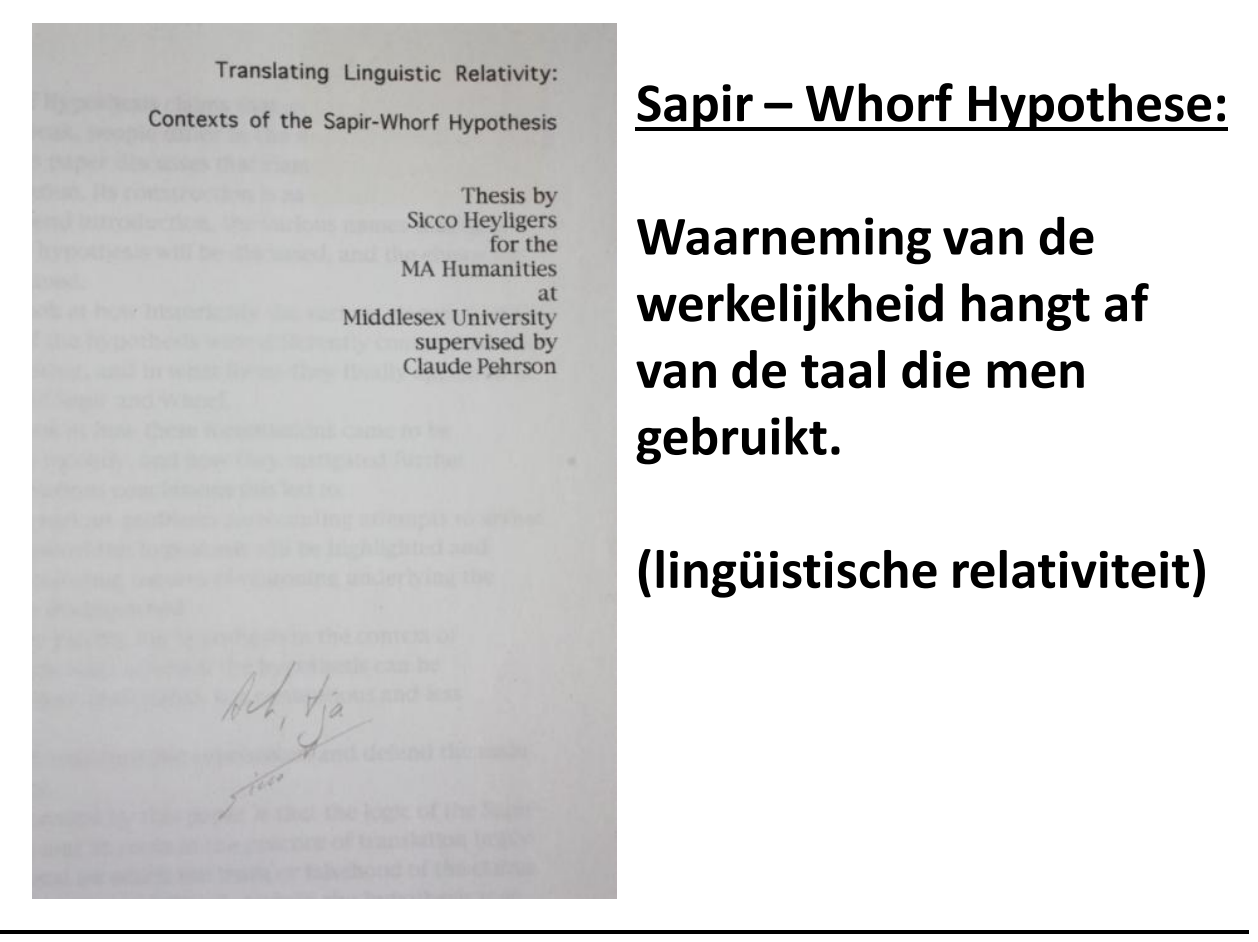


Van deze hypothese had ik waarschijnlijk nooit geweten als die niet was beschreven door mijn broer Sicco in zijn master scriptie voor de Universiteit van Middlesex in Engeland.

Juist hier, aan de Universiteit van Maastricht, de meest internationale Universiteit van Nederland met een lijfspreuk in het Engels ("Leading in Learning"), met het grootste aantal buitenlandse studenten en docenten in een regio met de grootste concentratie van dialecten, dicht bij meerdere taalgrenzen, juist hier is het goed dat wij ons realiseren dat het gebruik van een andere taal een andere kijk op de werkelijkheid tot gevolg kan hebben.

Dit inzicht is ook belangrijk bij de opleiding van artsen en specialisten. Niet zozeer omdat zij vaak in het Engels worden onderwezen, of omdat zij verschillende dialecten of talen spreken, maar vooral omdat dokters als het ware een eigen taal spreken en daarmee volgens deze hypothese een eigen werkelijkheid ervaren. Studenten en co-assistenten zullen deze taal nog niet geheel beheersen, en patiënten meestal geheel niet. Het is belangrijk dat artsen daar oog voor hebben, wie spreekt welke taal? En hebben we het wel over hetzelfde? Vandaar dat communicatie een belangrijk aspect is in de opleiding. Is men zich bewust van de kracht van de taal dan kan dat ook juist een voordeel zijn, een belangrijk instrument. Zo heb ik het begrip verbaal opereren geïntroduceerd, mijn studenten en assistenten zullen het zeker herkennen.

Verbaal opereren betekent dat met taal als instrument in het contact met de patiënt de arts secuur zijn weg vindt tussen gedachten, ideeën, veronderstellingen en overtuigingen om bij die patiënt het inzicht te verwerven dat nodig is voor zijn behandeling op dat moment, op dezelfde manier als dat de arts met het mes als instrument zijn weg vindt tussen anatomische structuren om bijvoorbeeld een heupprothese te plaatsen. Met het begrip "verbaal opereren" wordt een appél gedaan op het chirurgisch referentiekader van de arts -assistent. Hierdoor ontstaat begrip voor de communicatieve instrumenten die moeten worden aangeleerd om deze techniek te beheersen.

Bovendien wordt door gebruik van de metafoor van de operatie aangesloten bij de gedachten wereld van de assistent. Een bijkomend voordeel is dat indien een conservatieve therapie wordt voorgesteld in plaats van de gewenste 
chirurgische behandeling (de patiënt wil bijvoorbeeld een kunstheup terwijl de arts van mening is dat hij hier nog niet aan toe is, of de patiënt vindt dat zijn zeer ernstige rugklachten toch echt alleen maar met een operatie kunnen worden verholpen) de assistent zich realiseert dat hij (en overal waar ik hij zeg wordt ook zij bedoeld en voor de geneeskunde moeten we dit misschien wel om gaan draaien) maar goed dat hij dus niet alleen een behandeling NIET moet verrichten (de chirurgische operatie), maar dat hij een hele belangrijke behandeling juist WEL moet verrichten (de verbale operatie).

De verbale operatie techniek betekent dat woordgebruik en zinsbouw zo worden gekozen dat deze passen bij het beoogde doel van de verbale ingreep, bij de gewenste werkelijkheid. Indien de arts de patiënt ervan moet overtuigen dat een operatie zinloos is dan wordt bijvoorbeeld gezegd : "het is niet nodig dat we de messen slijpen, de heup eruit zagen en er een nieuwe in timmeren van ijzer en plastic". Heeft de patiënt daarentegen een zetje nodig om de verstandige beslissing te nemen zich te laten opereren dan zegt de arts: "we kunnen heel goed met een operatie het versleten gewricht vervangen door een kunstgewricht". De context waarin dit gebeurt verleidt als het ware, in de goede zins des woords, de patiënt om de juiste beslissing te nemen. Verbaal opereren is in feite de praktische toepassing van de Sapir - Whorf hypothese in de klinische praktijk. Het woord is soms scherper dan het mes.

Dit subtiele proces speelt een belangrijke rol in de kliniek, op de werkvloer, in de praktijk. Daar heerst de juiste authenticiteit die ervoor zorgt dat de adaptatie van Darwin en de Wet van Wolff hun effect kunnen hebben en dat gebruik kan worden gemaakt van de hypothese van Sapir - Whorf. Daarom is het zo belangrijk dat dokters worden opgeleid in een volledig functionerend ziekenhuis. Maar wel een ziekenhuis waar men oog heeft voor deze processen en daar rekening mee houdt; een opleidingziekenhuis.

Dit is ieder ziekenhuis waarin op alle niveaus en afdelingen medewerkers in opleiding zijn; artsen, specialisten, onderzoekers, verpleegkundigen, fysiotherapeuten, laboranten en nog veel meer. Opleiding bepaald de signatuur van het ziekenhuis, het bepaald als het ware de klank van het orkest. Dit betekent bv - als de casus dat toelaat - dat opvang op de eerste hulp eerst gebeurt door artsen in opleiding die daarna overleggen met hun bazen. In een opleidingziekenhuis snapt de specialist dat hij een corrigerende opmerking aan 
een van zijn assistenten volgens de Pemberton rules direct, concreet en specifiek moet maken. De vrouw (of man, alle variaties komen voor) van de specialist weet dat de aardappels wel eens wat later op kunnen omdat er nog een beoordeling gesprek moet gebeuren, of dat er veel meer aardappels moeten worden geschild omdat er co-assistenten uit India mee komen eten. In een opleidingsziekenhuis kan het gebeuren dat men een oriëntatiereis maakt naar India en China. Zo kan het gebeuren dat de arts-assistenten een presentatie horen over complementaire geneeskunde, een onderwerp waarin wij ver achter lopen bij bv de Amerikaanse medische faculteiten.

Natuurlijk is het heel goed om bepaalde onderdelen van het artsen vak te leren in een nagebootste situatie. De oog hand coördinatie kan men bv. beter eerst goed leren met een model. Een slecht nieuws gesprek, of omgaan met agressie kan goed worden geoefend met acteurs. Maar daarna moet de arts in opleiding het toch echt toepassen in de praktijk en dan zal blijken dat het gecompliceerder is dan hij dacht, dat er meer bij komt kijken. Golfen leer je maar ten dele op de driving range, in het echte spel ligt het balletje altijd net even anders (of je kunt het überhaupt niet vinden). Muziek maken leer je in de orkestbak. Wie wil leren zwemmen moet bereid zijn nat te worden.

Perspect Med Educ (2012) 1:6-14

DOI 10.1007/s40037-012-0002-7

REVIEW ARTICLE

Medical education: past, present and future

Geoff Norman

Published online: 7 February 2012

(c) The Author(s) 2012. This article is published with open access at Springerlink.com

Het is met schroom dat ik aangeef het geheel níet eens te zijn met de visie van Geoff Norman zoals hij deze beschrijft in zijn artikel "Medical Education: past, 
present and future". Bij deze reus uit het medisch onderwijs ben ik maar een mier; Norman is hoogleraar klinische epidemiologie, gepromoveerd natuurkundige, heeft een master in de psychologie, en is de auteur van 10 boeken en meer dan 200 artikelen veelal over medisch onderwijs. Maar hij is geen arts.

Norman stelt dat de vernieuwingen in het medisch onderwijs vooral hebben plaats gevonden in de pre-klinische fase en onvoldoende in de klinische fase. Door veranderingen in de gezondheidszorg; kortere opname duur, meer comorbiditeit, meer oudere patiënten, zou de kliniek minder geschikt zijn voor de opleiding van artsen. Hij pleit voor een soort parallel curriculum rondom geselecteerde klinische cases met digitale ondersteuning, buiten het ziekenhuis. Met zijn beschrijving van het verleden van het medisch onderwijs kan men het alleen maar eens zijn en ook zijn analyse van de huidige ontwikkelingen is grotendeels juist. Maar in plaats van het buiten de kliniek plaatsen van de klinische training pleit ik er juist voor om deze nog veel meer ín de kliniek te plaatsen.

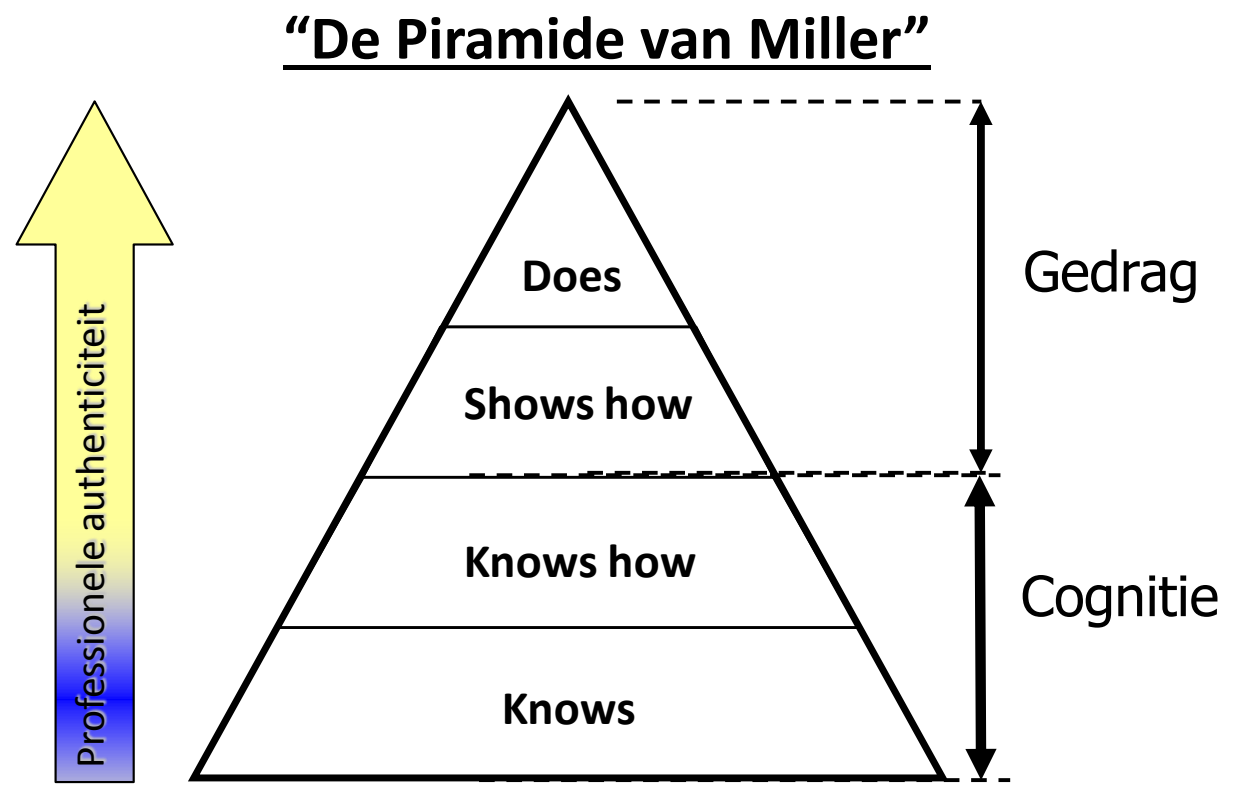

Miller GE. The assessment of clinical skills/competence/performance. Academic Medicine (Supplement) 1990.

De piramide van Miller schetst de opbouw gedurende de medische opleiding; van algemene basis kennis, dan meer specifieke kennis, via laten zien dat je iets kunt naar het zelf doen. Juist in de authentieke klinische situatie bestaat de ideale omgeving om dit aan te leren, te trainen, en te toetsen. Het gaat 
uiteindelijk om het kunnen en het doen, het ontwikkelen en tonen van specifiek gedrag. De arts en medisch specialist worden dan ook opgeleid tot het beheersen van competenties.

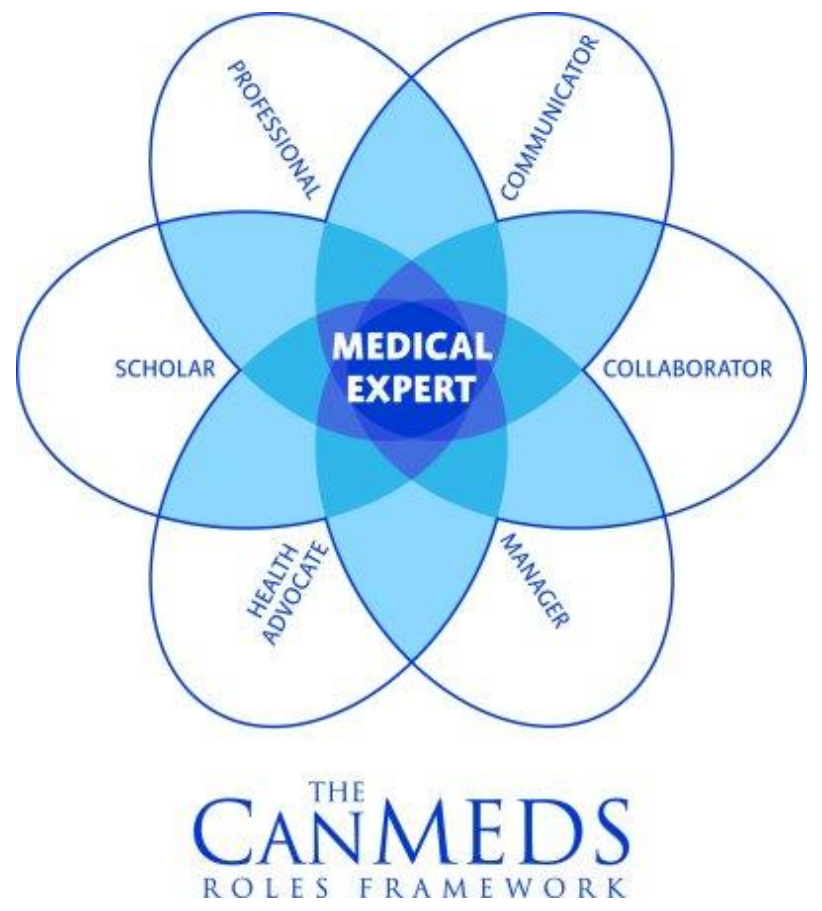

Men onderscheidt 7 competenties, die $U$ hier kunt zien, de zogenoemde CanMeds, een samentrekking van Canadian Medical Education Directives for Specialists. Een competentie is een bekwaamheid om een professionele activiteit in een specifieke, authentieke context adequat uit te voeren. Dit gebeurt door de geïntegreerde toepassing van het geheel van kennis, inzichten, vaardigheden en professioneel gedrag.

Deze specifieke, authentieke context bestaat in de kliniek en niet daarbuiten. De opleiding moet dus de kliniek in en niet eruit zoals bepleit door Norman. Maar wel met extra middelen en methoden, al dan niet digitaal. Bovendien bij voorkeur in verschillende klinieken in binnen- en buitenland, de arts in opleiding moet in verschillende keukens kijken, en dat hoeft niet alleen in sterrenrestaurants zoals in deze regio. 


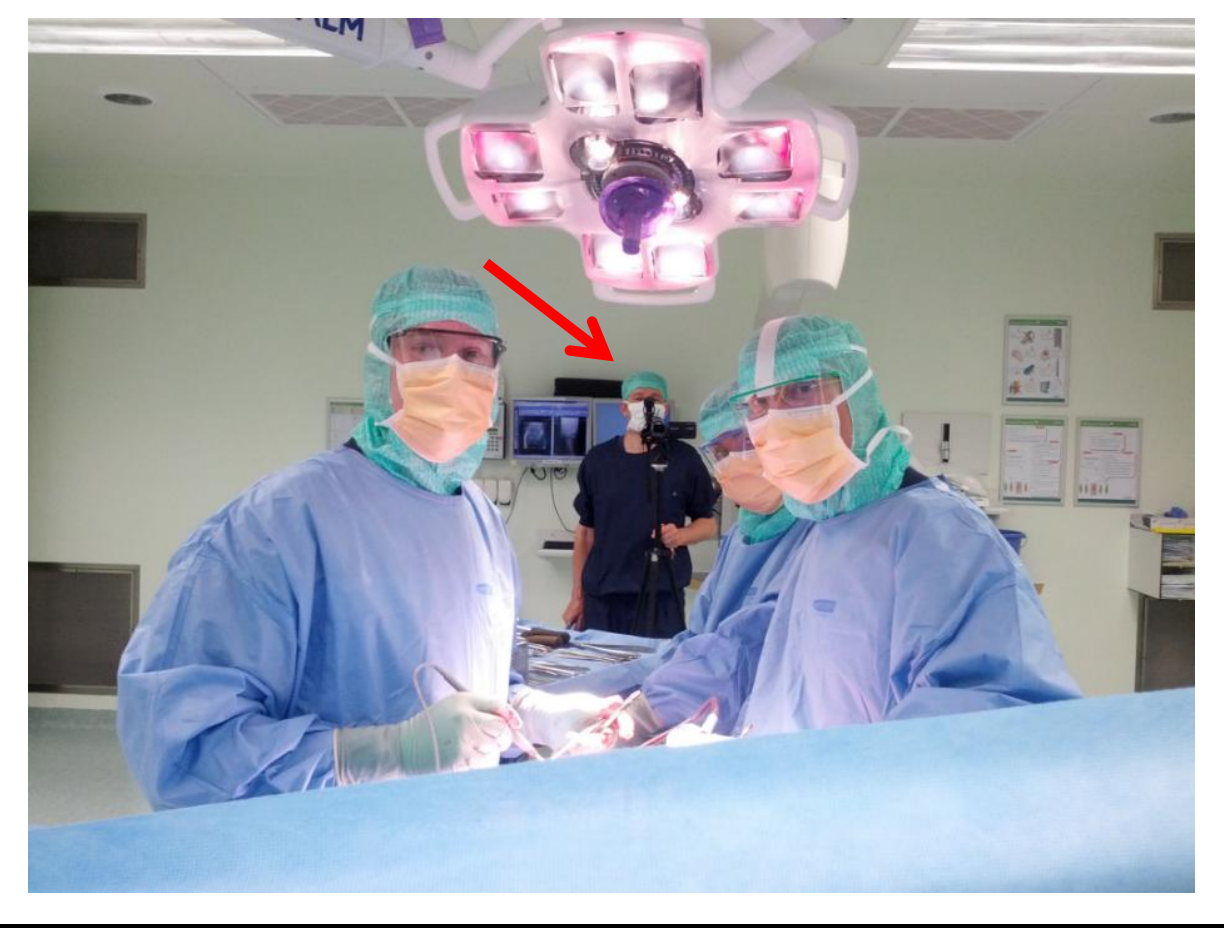

Een mooi voorbeeld van onderwijstechnieken in de kliniek is het maken van video opnamen tijdens het werk in het ziekenhuis; spreekuur doen, visite lopen, opereren ed.

Door deze opnamen met elkaar te bespreken, vaak onder leiding van een extern deskundige, krijgen dokters in opleiding belangrijk inzicht in het eigen functioneren, dat van de anderen en dat van de groep, het team. 


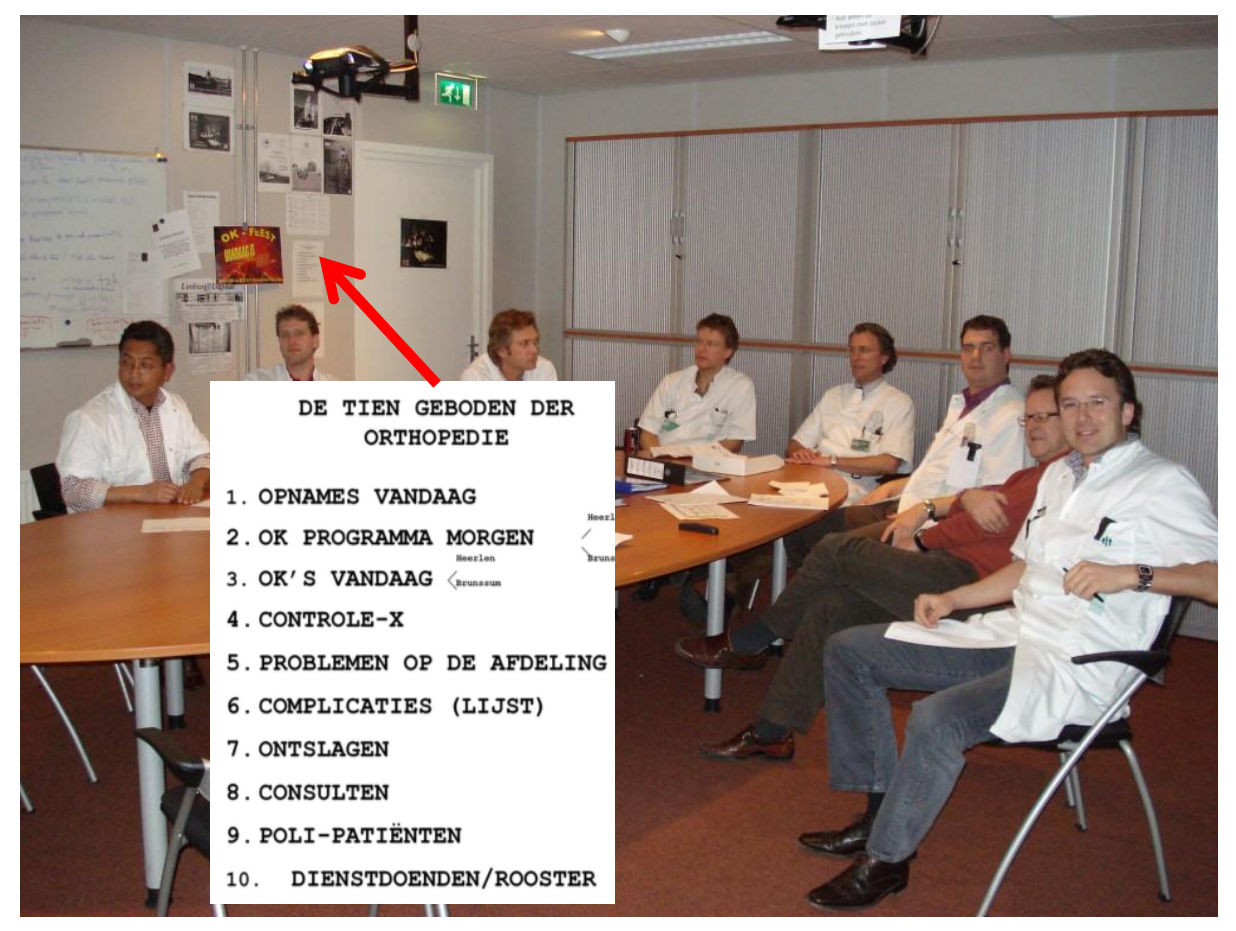

Een belangrijk instrument zowel voor de opleiding als voor de kliniek is de overdracht. Hier worden alle facetten besproken, alle competenties komen aan bod in een veilige sfeer. Deze dagelijkse bespreking is een belangrijke reden dat opleiding de kwaliteit van de kliniek ten goede komt. De overdracht is a.h.w. de avondmaaltijd van de opleidingsgroep. Om de assistenten een vaste structuur te bieden gebruiken wij de tien geboden die altijd in dezelfde volgorde worden behandeld. Door dit houvast kan de jongste assistent leiding geven aan de overdracht en weet iedereen altijd wat er zal worden besproken. Het gaat om de vaste structuur, voor andere afdelingen zal de inhoud wellicht anders zijn. Via een eenvoudig onderzoekje konden wij aantonen dat de assistenten significant meer tevreden zijn over de kwaliteit van de overdracht als de 10 geboden worden gebruikt. Zo hebben deze hun weg gevonden naar verschillende afdelingen in Nederlandse ziekenhuizen.

Ter ondersteuning van een veilige opleidingssfeer in het ziekenhuis hebben wij het open inloop spreekuur geïntroduceerd. ledereen in opleiding in het ziekenhuis wordt uitgenodigd om binnen te komen lopen als er iets speelt. Dit gebeurt op een vertrouwelijke basis in overleg met de betrokken student of assistent. Zo zijn vele artsen in opleiding en opleidingsgroepen geholpen met extra begeleidingstrajecten. Mits aan een aantal randvoorwaarden wordt voldaan, werkt dit uitstekend. Dit initiatief is dan ook overgenomen door de 
andere opleidingsziekenhuizen in deze regio en is landelijk bekend gemaakt middels een publicatie in Medisch Contact.

Als arts neem je belangrijke beslissingen, maar je werkt vrijwel nooit alleen. Alleen sta je nergens. Recent onderzoek suggereert dat de evolutie theorie van Darwin ook geldt op groepsniveau voor organismen die hebben leren samenwerken.

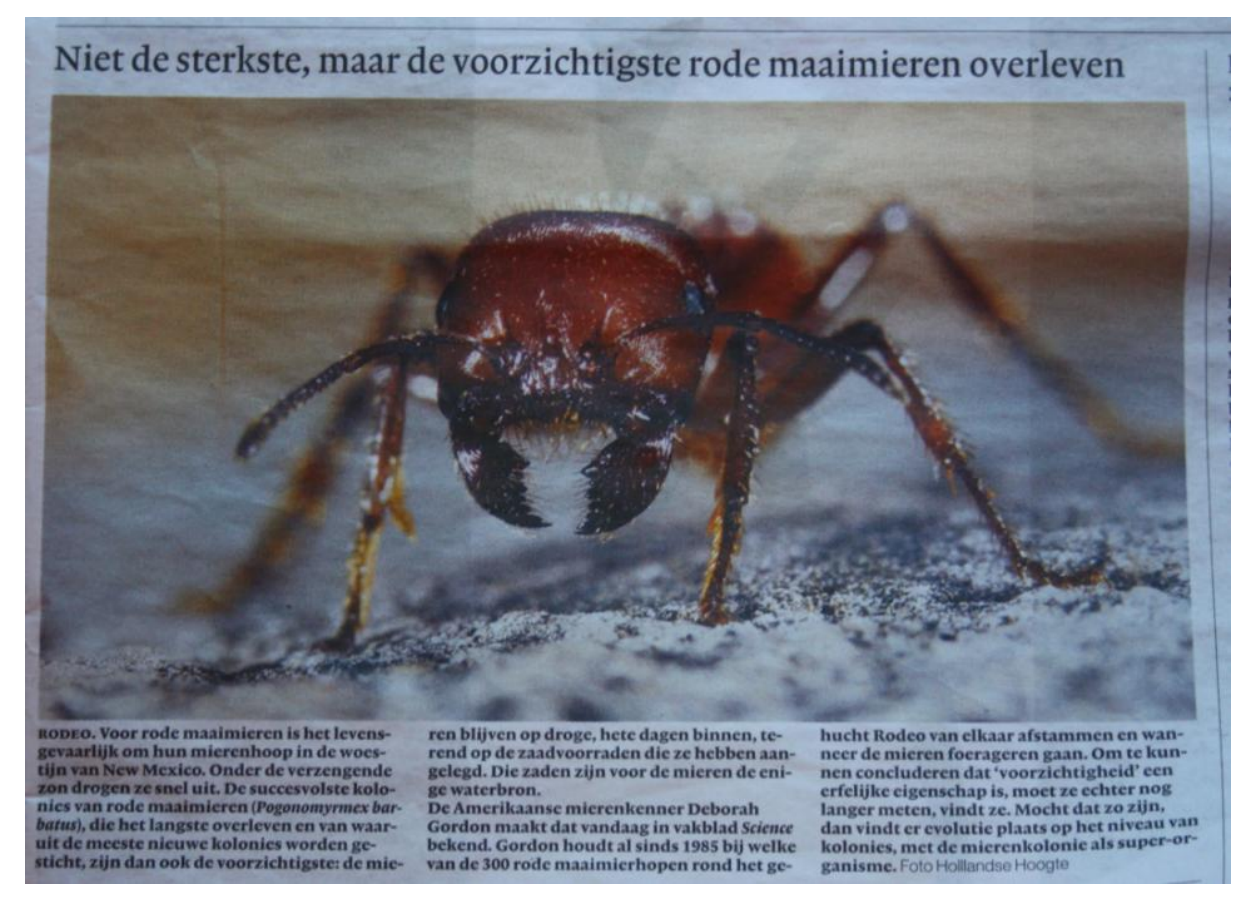

De Amerikaanse mierenkenner Deborah Gordon observeert al vanaf 1985300 rode maaimierhopen rond het gehucht Rodeo in de woestijn van Nieuw Mexico. Zij publiceerde in Science dat de succesvolste kolonies, met de meeste nakomelingen, de voorzichtigste zijn. Zij blijven bij hete dagen binnen en teren dan op de zaadvoorraden die zij hebben aangelegd. Zo voorkomen zij dat ze door de hitte buiten uitdrogen. Mogelijk vindt evolutie plaats op het niveau van kolonies. Zij die het beste samenwerken om voedselvoorraden aan te leggen zijn het meest succesvol. Wij mensen kunnen nog veel leren van mieren.

Ook scholing in wetenschappelijk onderzoek kan uitstekend plaats vinden ín de kliniek. In feite is wetenschappelijk onderzoek het stellen van de juiste vragen, het vinden van de goede antwoorden en deze vervolgens delen met anderen. Tijdens het werk in de kliniek ontstaan vanzelf deze relevante onderzoeksvragen. Als alleen dokters met elkaar vragen stellen en daar 
antwoorden op zoeken zullen ze echter minder ver komen dan wanneer zij daarin samenwerken met andere deskundigen. Vandaar dat het belangrijk is om voor het wetenschappelijk onderzoek andere disciplines in het ziekenhuis te halen en daar een structuur omheen te bouwen.

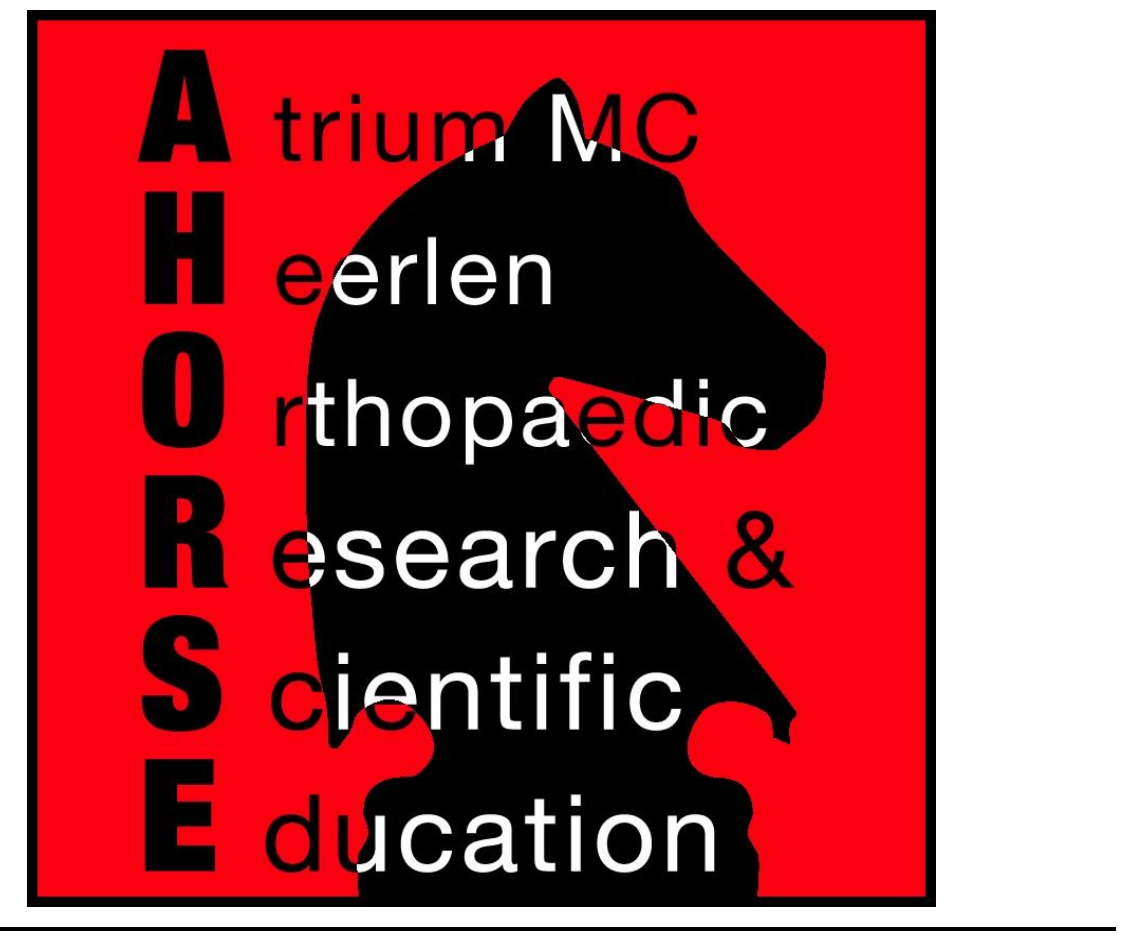

Wij hebben daarvoor de stichting AHORSE opgericht. Het logo hiervan is een paard; het dier dat afhankelijk is van zijn bewegingsapparaat om te overleven, maar dan het schaakstuk; 2 vooruit dan ineens 1 links of rechts, zo gaat het onderzoek ook vaak. In het logo is bovendien aan de onderzijde links en rechts de contour van het heupbeen te zien.

Vanaf de oprichting is daaraan verbonden Dr. Ir. Bernd Grimm, Duits ingenieur, gepromoveerd in Engeland en met een veelbelovende achternaam is als het gaat om publiceren. Samen hebben we de wetenschappelijk activiteiten uitgebouwd met diverse andere disciplines in binnen en buitenland. Zo werken studenten bewegingswetenschappen, geneeskunde, biomedische wetenschappen, ingenieurs en assistenten al vroeg in hun opleiding met elkaar samen. Dit heeft geresulteerd in een patent, meerdere onderzoekslijnen, publicaties en proefschriften. Twee weken geleden was ik nog de trotse promotor van Rachel Senden, een bewegingwetenschapper die nu mede het wetenschappelijk onderzoek coördineert, vooral van de studenten. Door onderzoekers met een andere achtergrond in de kliniek te halen ontstaat 
tijdens de opleiding de gewenste kruisbestuiving met de klinische praktijk. Ik laat $\mathrm{U} 2$ onderzoekslijnen zien als voorbeeld.

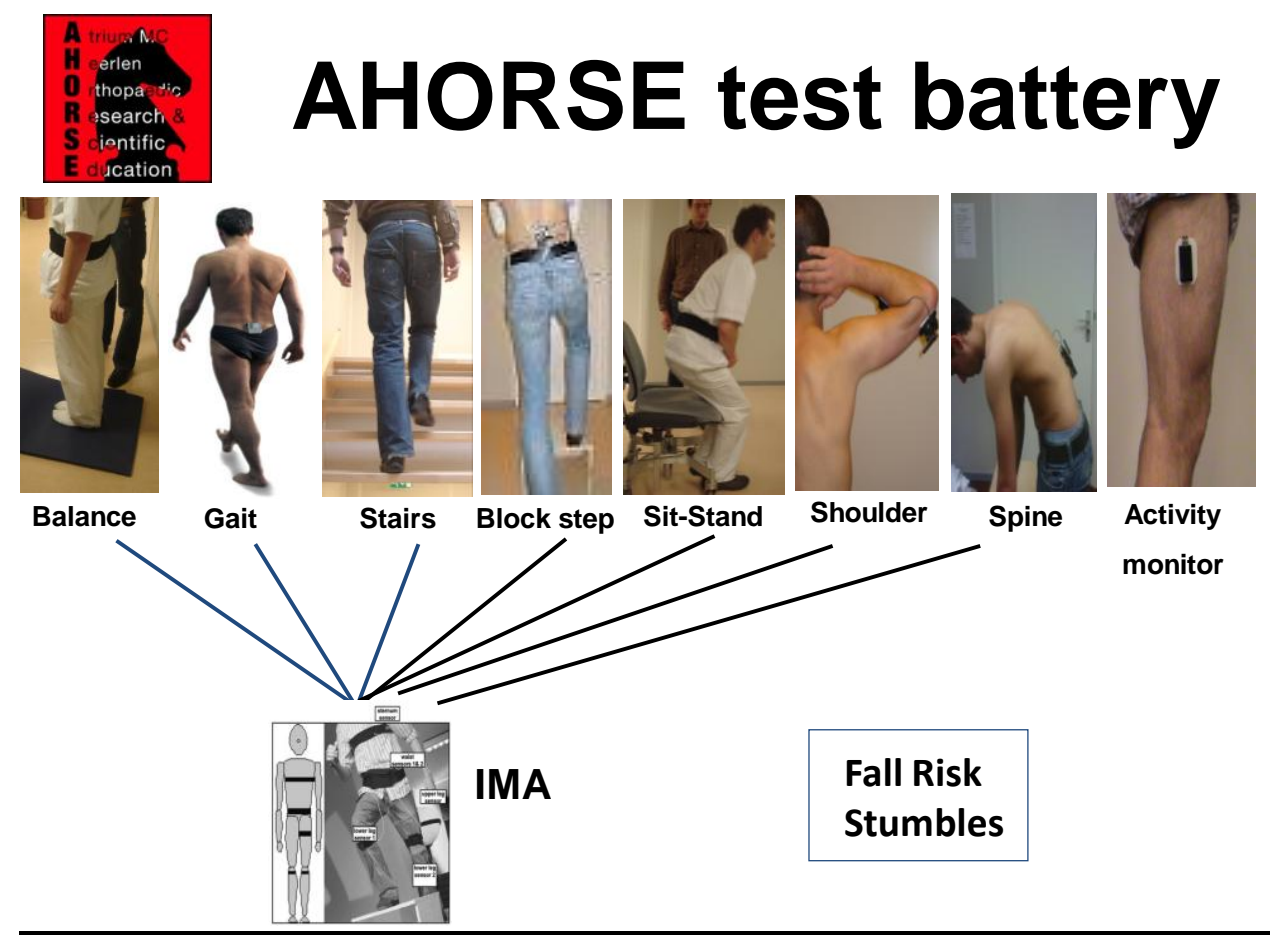

Ten eerste het gebruik van sensoren om objectief bewegingen te kunnen meten. In deze onderzoekslijn werken wij o.a. samen met de afdeling bewegingswetenschappen van deze universiteit. Zo zijn er een aantal protocollen ontwikkeld ( $U$ ziet hier een overzicht) waarvoor ook in het Manipal University Hospital in India metingen werden verricht. Met dit onderzoek proberen wij bv. in kaart te brengen welke patiënten wel en welke niet een verhoogd valrisico hebben, of patiënten met kanker zich beter voelen als zij meer bewegen, wat het optimale moment is van ontslag uit het ziekenhuis en hoe patiënten functioneren na een operatie. 


\section{Functioneren na plaatsen knieprothese}

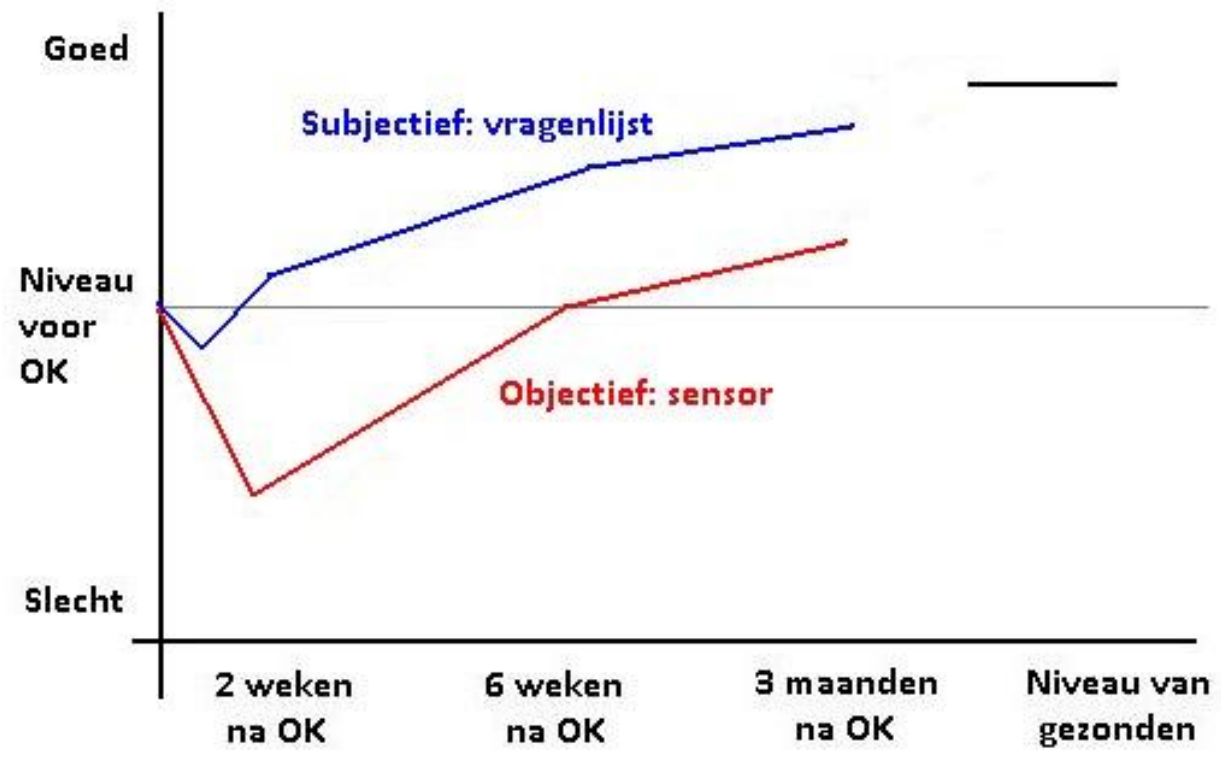

In deze grafiek ziet $U$ de verrassende bevinding dat patiënten zelf een veel sneller herstel rapporteren na een knie vervangende operatie (de bovenste lijn) dan wij objectief kunnen meten (de onderste lijn). Het verminderen van pijn door de operatie speelt hierin waarschijnlijk een grote rol. Over de subjectieve beleving en de objectieve bevindingen rond ziekte en gezondheid kunnen wij nog veel leren. 


\section{Subjects and Methods: CT Femur}

\begin{tabular}{|c|c|c|}
\hline & $\begin{array}{c}\text { Octogenerian } \\
\geq \mathbf{8 0 y r s}\end{array}$ & $\begin{array}{c}\text { Control group (old) } \\
<\mathbf{8 0 y r s}\end{array}$ \\
\hline $\mathbf{N}$ & 119 & 51 \\
\hline Age & $84.1 \mathrm{yrs}[80-105]$ ) & $67.8 y \mathrm{ys}[39-79]$ \\
\hline $\mathbf{M} / \mathbf{F}$ & $\mathrm{m}=65 / \mathrm{f}=54$ & $\mathrm{~m}=36 / \mathrm{f}=15$ \\
\hline
\end{tabular}
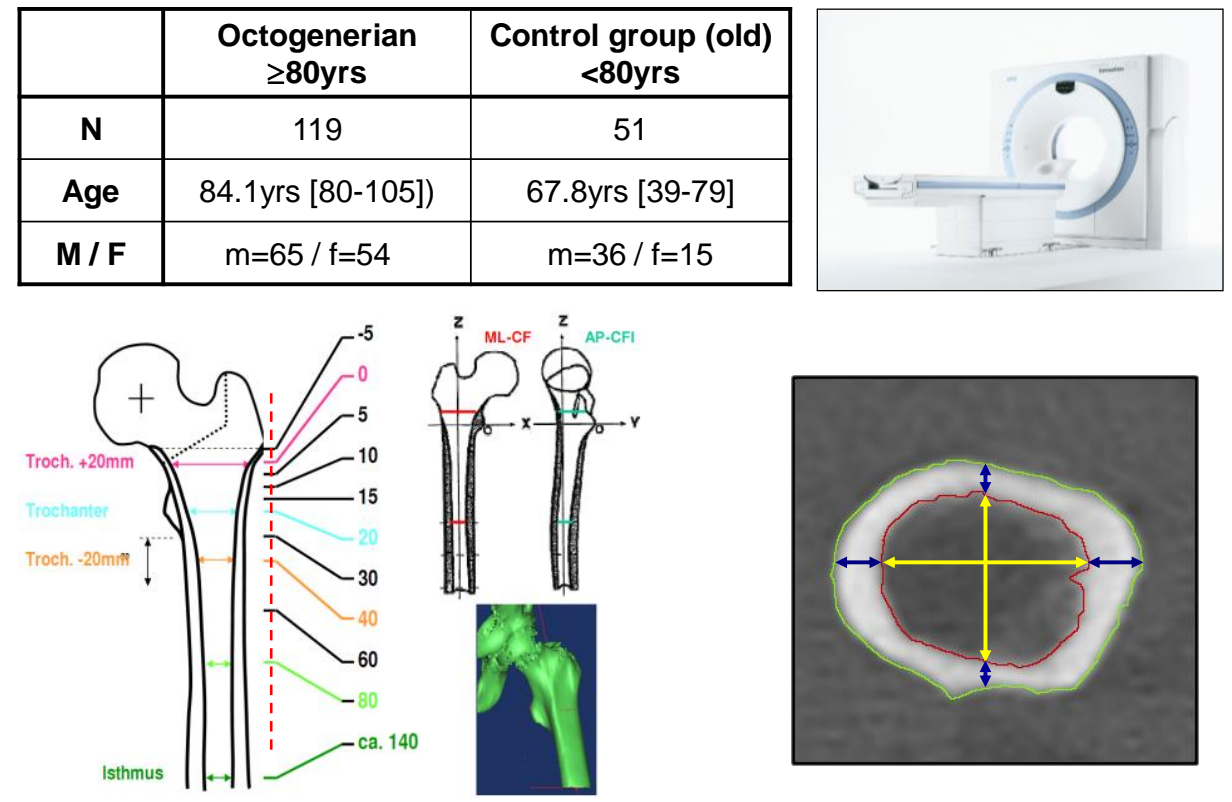

In een andere onderzoekslijn meten wij de drie dimensionale veranderingen die plaats vinden in de architectuur van het dijbeenbot gedurende veroudering, en de verschillen die hierbij bestaan tussen mannen en vrouwen.

Deze gegevens zijn van belang bij de behandeling van ouderen met een breuk of slijtage van het heupgewricht. Aan een unieke data base - het voordeel van grote aantallen patiënten die bereid zijn om mee te doen aan onderzoek worden met computer programma's diverse berekeningen gedaan. Dit onderzoek doen wij samen met de Universiteit van Houston in Texas, waar Tim Boymans, een van de assistenten in opleiding, een half jaar is geweest mede dankzij een Fulbright beurs. 


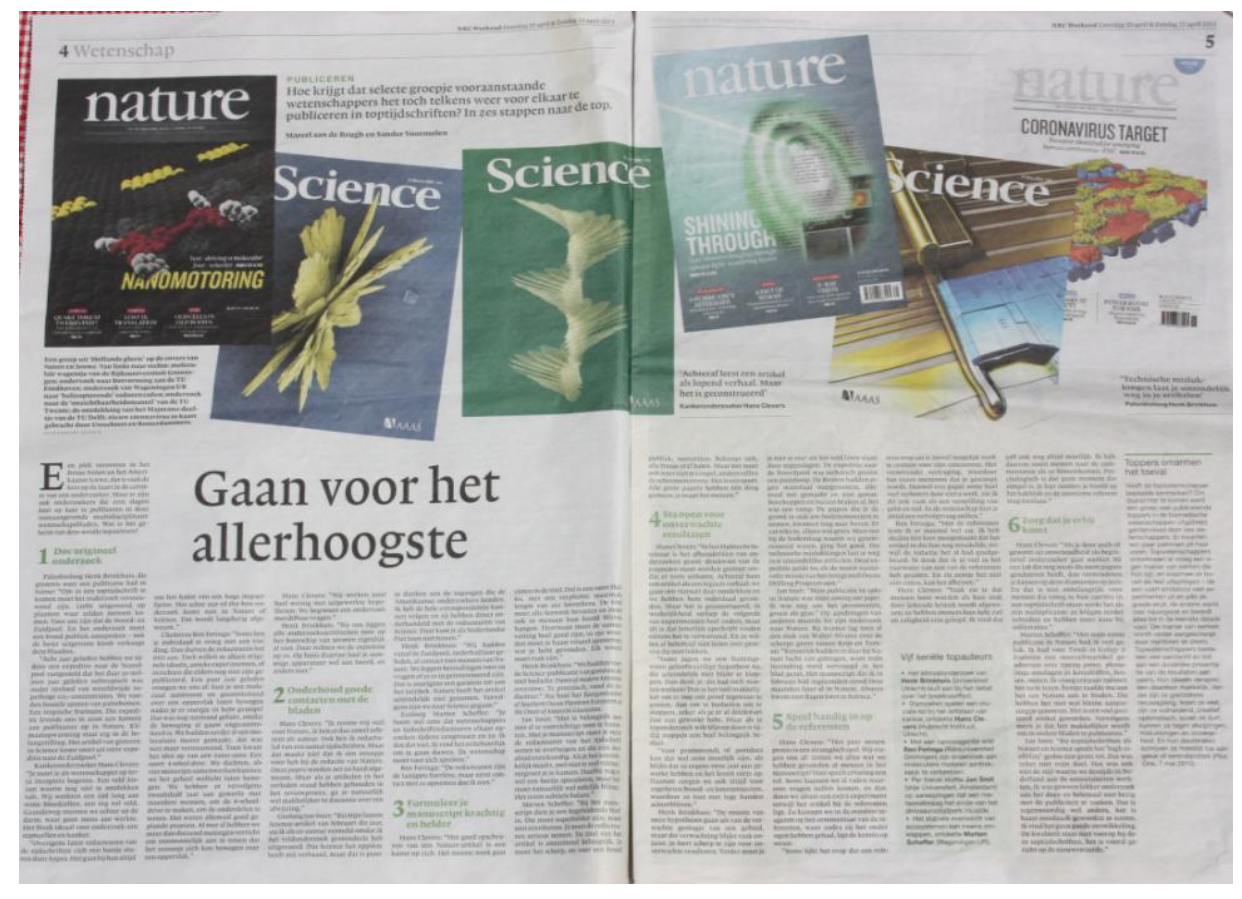

Voor wetenschappelijk onderzoek is het overigens belangrijk om een sfeer te creëren waarin vooral veel kan maar weinig hoeft. Interview van een groep top onderzoekers in de biomedische wetenschappen leerde dat zij een heel eigen manier van werken hebben; ze zijn grenzeloos nieuwsgierig, lezen veel, zijn creatief, volhardend, optimistisch, tonen durf en kunnen tegen afwijzingen, mislukkingen en onzekerheid. (Overigens allemaal eigenschappen van goede artsen.) Hun doorbraken schrijven deze topwetenschappers meestal toe aan geluk en serendipiteit.

In het Institute For Advanced Study van Princeton, waarvan Robbert Dijkgraaf recent is benoemd tot directeur, bestaat de grootste concentratie van top wetenschappers. 


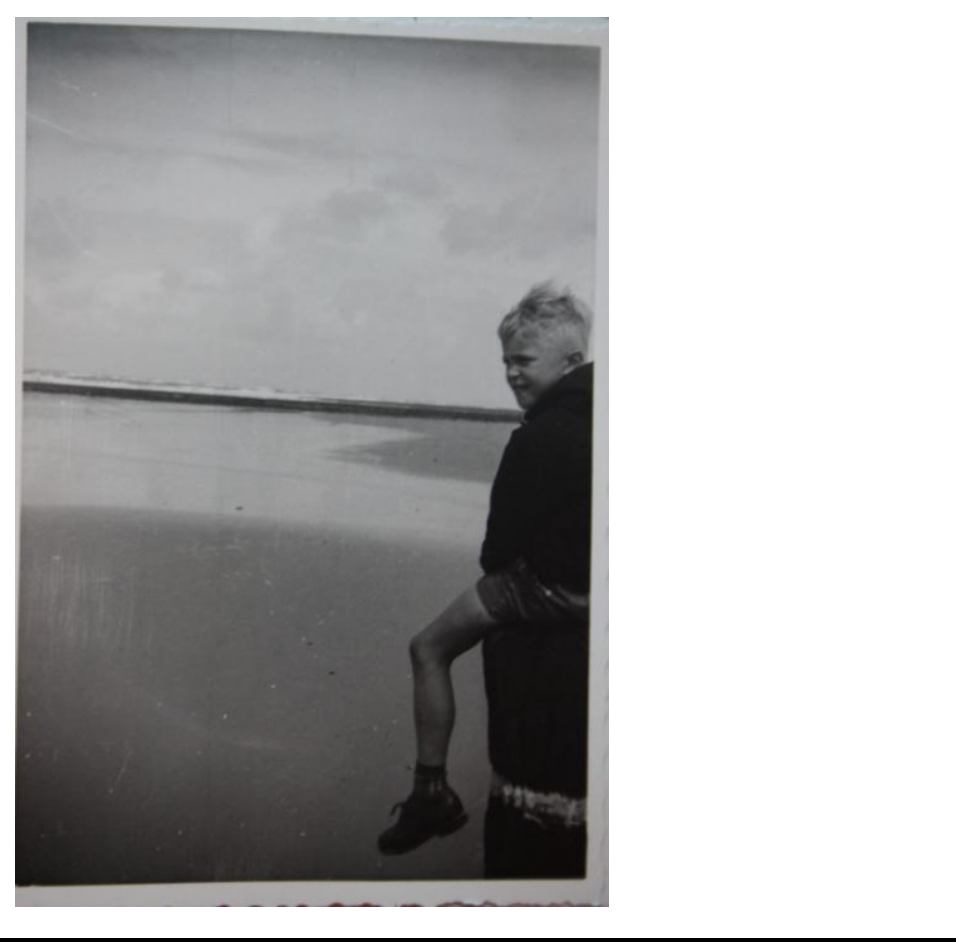

Deze krijgen alle mogelijkheden om geheel naar eigen inzicht de dag door te brengen, met wetenschap, maar ook met lummelen, paalzitten, bijen houden of wat dan ook. De eerste directeur van dit Instituut was Abraham Flexner, een onderwijskundige die in Amerika aan de wieg heeft gestaan van de huidige medische faculteiten. Hij sprak over de 'language of biomedical science' geheel in overeenkomst met de hypothese van Sapir-Whorf. Geneeskunde, onderwijs en wetenschap zijn onverbrekelijk met elkaar verbonden. Voor wetenschappelijk onderzoek is het belangrijk om soms niets te doen. Ik ben dan ook erg voor het paalzitten (maar ik doe het te weinig).

Er zijn meer redenen om de opleiding ín de kliniek te halen en niet andersom. Het nivo van de gezondheidszorg in Nederland staat op zeer grote hoogte, maar er zijn diverse uitdagingen; de vergrijzing, te weinig personeel, onbetaalbare kosten van zorg én van opleiding, de disbalans tussen cure en care, tussen economische winst en gezondheids winst, de verminderde invloed van de arts op het medisch proces waar hij wel verantwoordelijk voor is en nog heel veel meer. Deze onderwerpen zitten verankerd in het dagelijks werk in de kliniek. 


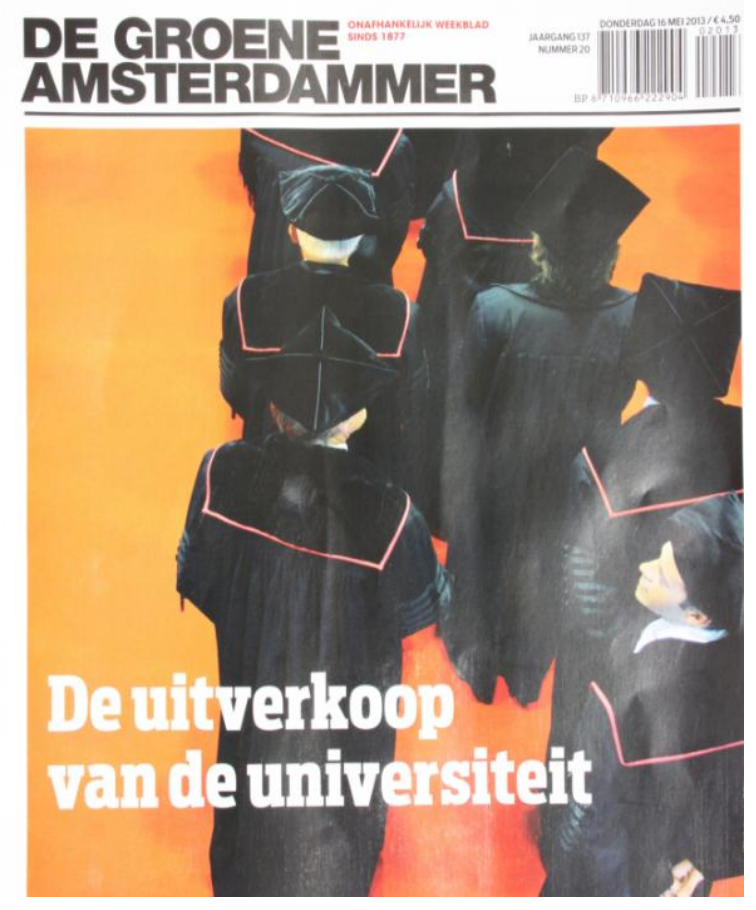

Een van de uitdagingen is de invloed van de marktwerking. Zoals deze in het wetenschappelijk onderwijs zijn sporen achterlaat, zo speelt deze ook een rol in de medische vervolgopleidingen. Het opleiden van een medisch specialist kost grof geschat een miljoen euro. Wordt de opleiding niet afgemaakt dan brengt dit bedrag niet de verwachte investering op. Het is echter vele malen belangrijker dat opleiders alleen de laatste handtekening zetten na opleiding van een specialist als zij overtuigd zijn van zijn of haar functioneren. Kortzichtig zou men kunnen stellen dat een begonnen opleiding, gezien de investering moét worden afgemaakt. Gelukkig is dat niet zo en erkent men de deskundigheid van de opleidersgroep, de kunde én de kunst van het opleiden. De financiering is echter niet goed geregeld. De discussie over de kosten van het opleiden van artsen laat zien dat wij alert moeten zijn. Wij moeten onze verantwoordelijkheid nemen, zowel voor de kwaliteit als voor de kosten. In de gezondheidszorg zelf is dit uit de hand gelopen; het markt denken heeft erin geresulteerd dat mij als medisch manager volkomen legaal werd gevraagd om zorgproducten te ontwikkelen waar winst mee zou kunnen worden gemaakt, zonder dat hier blijkbaar een medische vraag naar bestond, tegelijkertijd werd gevraagd om het aantal schouderimplantaties te beperken omdat dit te veel geld zou kosten, terwijl voor deze operaties wel een indicatie bestond. De Nederlandse verzekeraars vergoeden het plaatsen van een Metal - on - Metal heupprothese in België. Een operatie waarvan de Nederlandse Orthopaedische 
Vereniging terecht heeft besloten deze niet meer uit te voeren gezien de slechte resultaten. Diezelfde verzekeraars vergoeden vervolgens de revisie operatie in NL als wij de heup vervangen door een goeie. Wij moeten een andere manier ontwikkelen om zaken te waarderen, zoals de aan Harvard verbonden filosoof Michael Sandel zegt; "de moraal moet terug in het debat". Gezien hun maatschappelijke positie moeten artsen in dit debat een belangrijke rol spelen, dit begint in hun opleiding.

Door in de kliniek de dokters van morgen op te leiden betrekt men hen bij deze onderwerpen. Daarom dat ook politici, bestuurders, verzekeraars en economen mee moeten doen aan de opleiding van artsen. Wij moeten daarbij creatief zijn en out of the box denken. Om dat te stimuleren hebben we kunstenaars nodig die getraind zijn om onconventioneel te denken en te kijken.

Toen wij de Amsterdamse kunstenaar Jeroen Werner een dagje lieten meelopen in het ziekenhuis kwam hij met veel verrassende observaties en bevindingen; bv. dat in de hal de bloedafgifte balie zich bevindt naast de geldopname, a.h.w. de bloedbank naast de geldbank.

Ook deed hij de simpele maar briljante suggestie om op de hoogste verdiepingen van het ziekenhuis verrekijkers te plaatsen. Zo kunnen patiënten uitkijken over het prachtige landschap en zich virtueel verplaatsen buiten de ziekenhuismuren. Ik ben erg voor een klinisch consult kunstenaar.

In de toekomst moeten wij de gezondheidszorg gezond houden wellicht met andere middelen, in een andere structuur in een veranderende samenleving. De artsen van morgen moeten worden opgeleid in het hart van deze veranderende structuur, midden in de gezondheidszorg, midden in het ziekenhuis, door praktiserende artsen met de bloedvlekken op de klompen en niet buiten het ziekenhuis door niet-artsen met de koffievlekken op de gaatjesschoenen.

Al vroeg in de medische studie leren studenten in de kliniek. Geleidelijk doorlopen zij het traject van co-assistent, semi-arts, arts-assistent tot uiteindelijk medisch specialist. Tijdens dit traject ontwikkelen zij de gewenste competenties en krijgen steeds meer verantwoordelijkheden. Bovendien ronden zij vaak een proefschrift af; in deze regio streven wij ernaar dat $20 \%$ van de arts-assistenten in opleiding een promotie traject doorloopt. Dit geheel 
van oplopende stappen in de klinische opleiding noemen wij het opleidingscontinuüm. Hierin vindt een dakpansgewijze opbouw plaats van supervisie en begeleiding van de jongere jaars door de oudere jaars onder de paraplu van de medisch specialisten. Zo leert men als onderdeel van de opleiding om zelf ook op te leiden. De specialist in opleiding moet geen trucjes leren, maar competenties verwerven. De kundigheid die hij in blokonderwijs heeft geleerd moet in lijnonderwijs onderhouden worden, in de veilige structuur van het opleidingziekenhuis.

Er zijn hierbij veel boeiende onderzoeksvragen; wat zijn de beste assistenten? Hoe we kunnen die selecteren? Wat is ervaring precies? Waarom kunnen we het zo moeilijk over brengen? Waarom doet de ene opleidingsgroep het zo veel beter dan de andere? Kun je passie meten? Voorspellen? Ontwikkelen? Hoe kunnen we opleiding en klinisch werk beter combineren? Hoe betrekken we de assistenten bij de begeleiding van de co-assistenten zodat dit in hun beider voordeel is? Hoe zorgen we dat de arts van morgen invloed blijft houden op het proces waar hij ook verantwoordelijk voor is? Als we meer op competenties gaan beoordelen, verdwijnt dan de vaste opleidingsstructuur en wordt deze individueel? Hoe regelen we dat dan? Dagelijks kunnen we in de krant lezen wat het effect is van een gebrek aan - wat in de literatuur wordt genoemd clinical leadership. Hoe ontwikkelen we dat? En wanneer, bij wie? Over dit soort onderwerpen verwacht ik dat we de komende tijd nieuwe inzichten zullen verwerven. Vooral door intensieve samenwerking vanuit de klinische opleidingspraktijk met de afdeling Onderwijs Ontwikkeling en Onderzoek van de Faculty of Health Medicine and Life Sciences van deze Universiteit.

Twee belangrijke spelers die wij nog te weinig betrekken in het proces van de klinische opleiding zijn de student/assistent die wordt opgeleid en de patiënt. De arts in opleiding weet vaak haarfijn wat hij nog moet leren en waar hij dat het beste kan krijgen. De patiënt kan heel goed bepaalde competenties beoordelen. Ondersteuning van opleiding door gebruik van video en andere technieken zal verder ontwikkeld worden. Wij moeten daarbij echter slimmer zijn dan anderen en niet klakkeloos technieken kopiëren; een operatiekamer is geen cockpit; in een ok spelen meer verschillende processen waarin meer personen acteren met een verschillende opleiding en verschillende verantwoordelijkheden. 


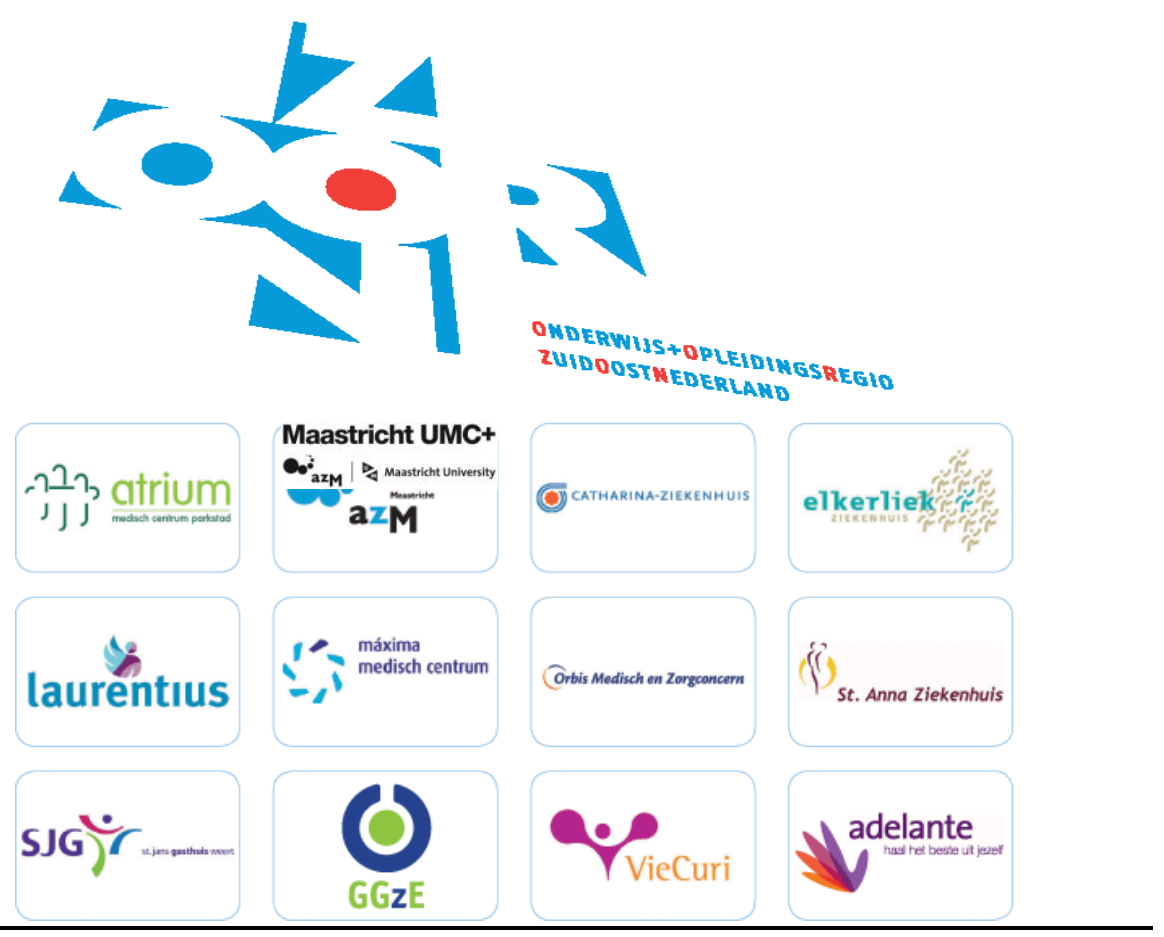

In de uitvoering en ontwikkeling van het opleidingscontinuüm wordt in deze regio, de Onderwijs en Opleiding Regio Zuid Oost Nederland oftewel de OORZON, samengewerkt door 12 ziekenhuizen en organisaties waarin ruim 1100 co-assistenten worden opgeleid tot arts en ruim 600 artsen worden opgeleid tot medisch specialist. Ik ben benoemd tot hoogleraar 'onderwijs en opleiding in het opleidingziekenhuis' en deze leeropdracht laat zien dat deze universiteit haar wereldfaam op het gebied van medisch onderwijs waarmaakt. Een hoogleraar dient echter vooral leraar te zijn. Vorm komt na functie en de binnenkant is belangrijker dan de buitenkant. Hier wordt in de praktijk toegepast wat wellicht nog moet worden bewezen, dat de theorie van Darwin geldt voor samenwerkende groepen. Zo wordt de leuze van deze universiteit 'leading in learning', in de kliniek gevolgd door 'learning by doing' en doordat opleiding de klinische kwaliteit verbeterd in 'leading in doing'. Onderwijs en opleiding in het ziekenhuis komen altijd de kwaliteit van de patiëntenzorg ten goede. Deze twee kunnen niet los gezien worden van onderzoek, dit is een drie-eenheid. 


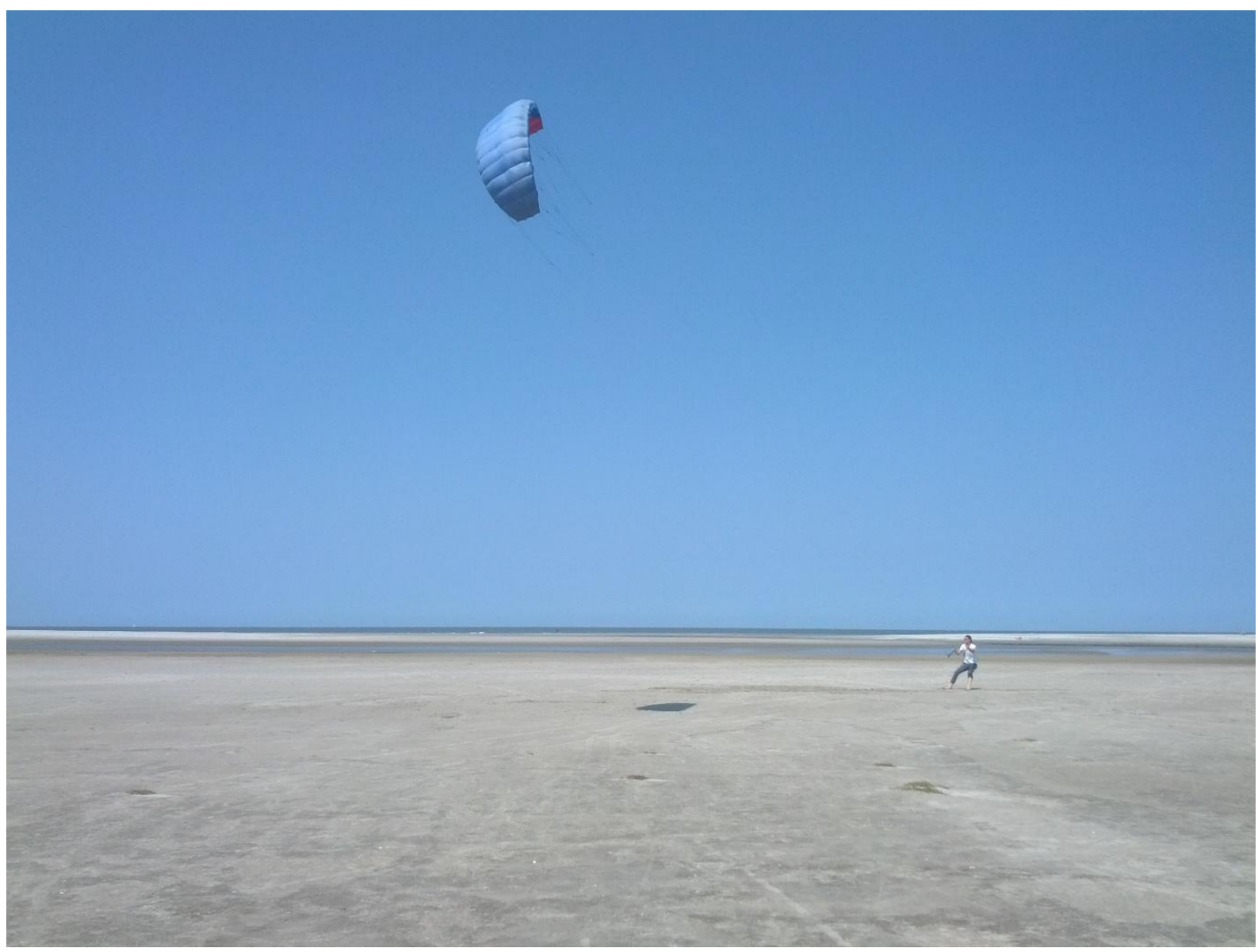

Opleiden is als vliegeren. Als zoon van een Delfts ingenieur vliegtuigbouw heb ik dat goed geleerd aan de Hollandse kusten. Bij vliegeren is een goede vlieger nodig en wind. Vaak moet men eerst een stuk rennen om de vlieger de lucht in te krijgen tégen de wind in. Heeft deze zijn weg gevonden dan moet de opleider vooral laten vieren. De vlieger zal zelf zijn koers kiezen, omhoog tegen de wind in, mits deze goed wordt geleid. Is er geen of onvoldoende wind dan lukt het niet. Opleiden in een situatie zonder voldoende leersituaties lukt ook niet, er moet voldoende opleidingscapaciteit zijn. Een vlieger moet ook aan bepaalde basis eisen voldoen; er moet draagvlak zijn, het touw moet voldoende sterk en voldoende lang zijn. De vliegeraar/opleider moet weten hoe hij de vlieger op laat tegen de wind in en hij moet bereid zijn om te vieren. Staat de vlieger mooi hoog in de lucht met het gehele touw strak gespannen dan vindt er na verloop van tijd een belangrijke transformatie plaats. 


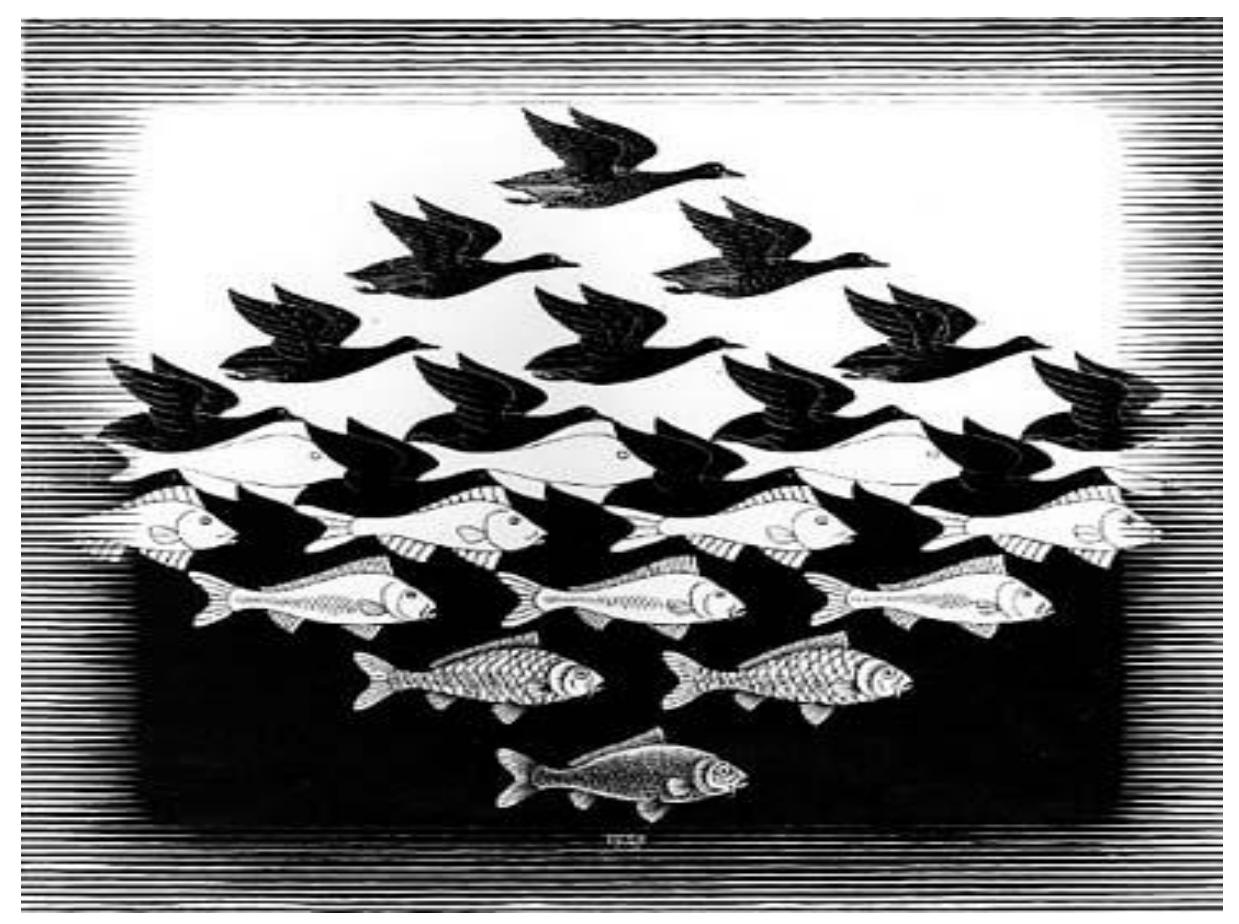

Terwijl een vlieger die wordt losgelaten vroeg of laat neer zal tollen, ontwikkeld de klare arts het vermogen om zelf te vliegen. Als dit moment is aangebroken dan moet de vliegeraar/opleider los kunnen laten; een moeilijke opdracht voor veel mensen. Op eigen gelegenheid zal de arts zijn weg vervolgen, als een vrije vogel die zich heeft los gemaakt uit de structuur.

De kunst van het opleiden is het herkennen van een goede vlieger en goed vliegerweer; voldoende wind, een gezond opleidingsklimaat. Het mooiste is een heldere, klare lucht. Gebakken lucht is heel slecht voor een gezond opleidingsklimaat. De opleider moet weten wanneer hij los kan laten, wanneer de arts op eigen kracht verder kan. 


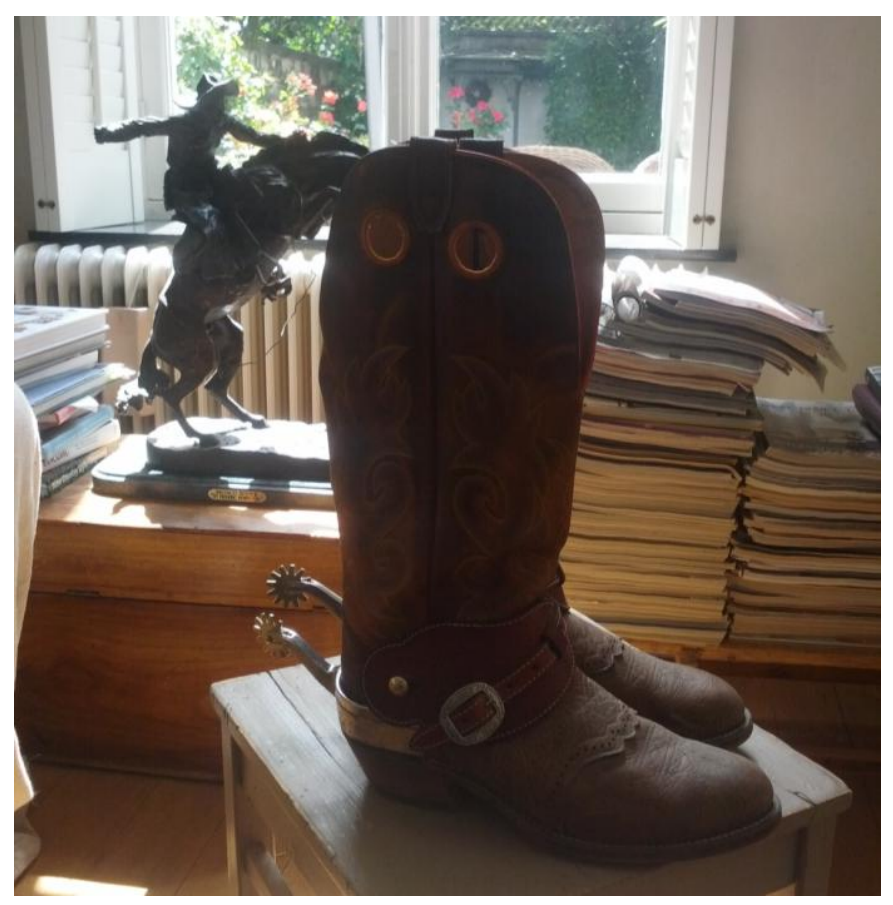

Wanneer de arts die is opgeleid zijn sporen heeft verdiend.

We hebben al eerder gezien dat we van maaimieren kunnen leren; vuurmieren bouwen bij een overstroming een levend vlot door elkaar vast te houden. Zo redden zij de kolonie.

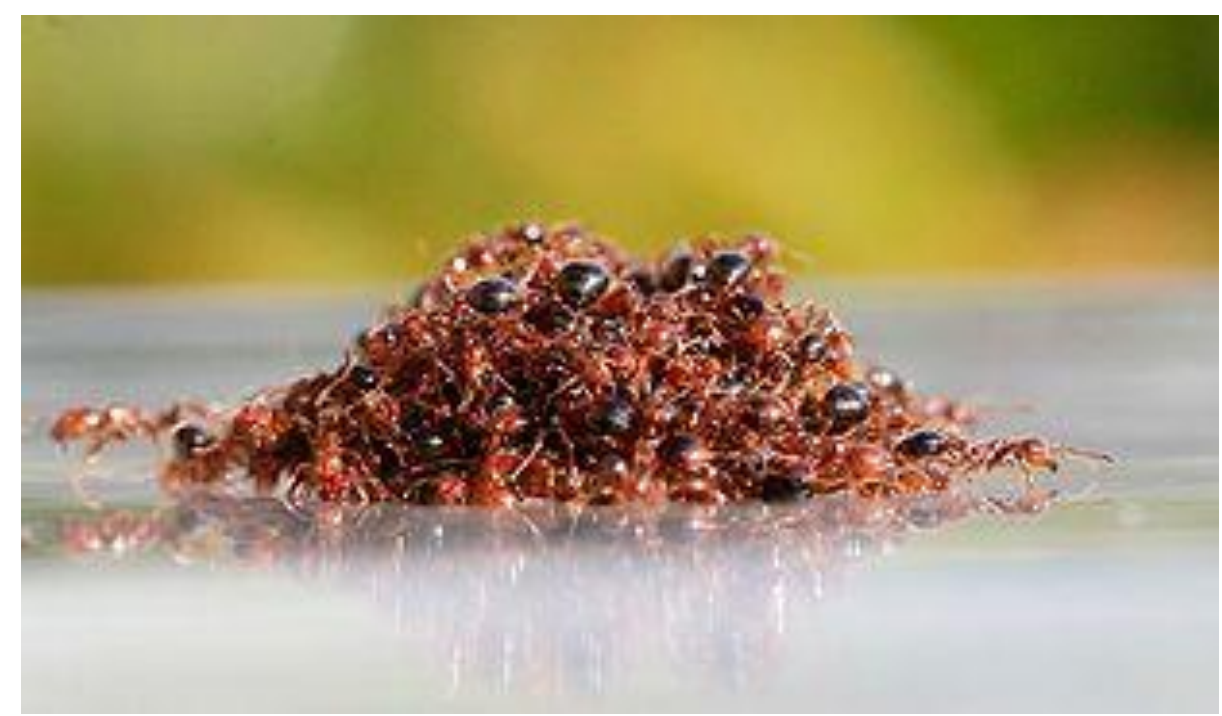


Zijn zij op het droge dan laten zij elkaar weer los en neemt ieder zijn taak weer op. Nu ben ik in deze hoogst gelegen regio van Nederland niet zo bang voor overstromingen. Maar dit is wel een mooi voorbeeld van optimale samenwerking voor een gemeenschappelijk doel.

Met de concentratie van patiënten groepen in bepaalde ziekenhuizen bestaat er voor de opleiding een nog grotere noodzaak om goed samen te werken tussen deze ziekenhuizen. Zo kan de opleidingscapaciteit optimaal worden benut door assistenten de gelegenheid te geven dáár te zijn waar zij het meeste kunnen leren. Ik ben er dan ook erg voor om de assistenten te betrekken bij het optimaal benutten van de opleidingscapaciteit. Het zou mooi zijn om de verdeling en financiering van de opleiding vanuit een centrale groep relevante vertegenwoordigers te regelen, gericht op opleidingskwaliteit. Ik ben ervan overtuigd dat dit kan ook in het belang van de kliniek. Kwaliteit van opleiden wordt dan beloond. Dit zeg ik met de wetenschap dat de opleidingscapaciteit en dus ook het vliegerweer in deze Onderwijs en Opleiding Regio Zuid Oost Nederland uitstekend zijn.

Dames en heren, leren zit in onze genen en in onze botten. Wij - mensen - zíjn een lerende organisatie. De vlieger wil vanzelf omhoog. Bij het opleiden van artsen moeten wij samenwerken om dit proces te faciliteren, daarvoor moeten we elkaars taal begrijpen en verbaal kunnen opereren. Door goed op te leiden bereiden wij de artsen en medisch specialisten adequaat voor op hun boeiende taak en voorkomen wij dat, eenmaal aan het werk, zij Darwin zullen citeren en zeggen: "Heel langzaam nam het ongeloof bezit van mij, maar het deed dit tenslotte geheel". Ik zal mij maximaal inzetten voor een optimale opleiding.

Nu ik gekomen ben aan het einde van mijn Oratie wil ik hen bedanken die bereid waren mijn vlieger op te laten en uiteindelijk los te laten en hen met wie ik samenwerkte; de bioloog Charles van Schaik, die als practicum begeleider vergelijkende anatomie aan de VU, (nu afgeschaft vanwege de kosten), mij belangrijke basis kennis gaf, postuum Prof. Rob Wesdorp die mij als coassistent vroeg of $\mathrm{ik}$ bij hem geen chirurg wilde worden en toen ik hem zei dat ik onderzoek wilde doen en orthopaedisch chirurg wilde worden mij niet liet vallen, maar mij zette op het spoor van de Fulbright beurs, mij introduceerde bij de orthopaedie en vervolgens mijn chirurgische vooropleider werd en ik zijn eerste promovendus. Van hem heb ik veel geleerd, o.a. hoe je leiding kunt 
geven, Prof. Lamar Fleming die mij liet kijken in zijn keuken van de afdeling Orthopaedie van Emory University in Atlanta, USA, de Fulbright organisatie die mij een beurs toekende om in Amerika onderzoek te doen, Prof. Myron Spector met wie ik een jaar samenwerkte aan Emory en Harvard University en die mij leerde dat wetenschappelijk onderzoek een vak op zich is.

Prof. Ton van der Linden, die soms alleen maar in de status in priegelschrift schreef "gepraat", als een kort verbaal operatie verslag, dank ik omdat hij mij tot orthopaedisch chirurg heeft opgeleid. De hooggeleerden Henk Haarman en Peter Patka, bedank ik voor de prima begeleiding toen ik wetenschappelijk onderzoek combineerde met de opleiding. Fons Tonino dank ik voor zijn opleiding en zijn vertrouwen toen hij mij vroeg de opleiding van hem over te nemen. Ik dank de collega stafleden met wie ik samen werkte zowel in de VU als hier, die een vreemde eend in hun bijt kregen en van wie ik veel heel verschillende zaken heb geleerd. Pieter van Akkerveeken, Netty Versloot en de medewerkers van Rug Advies Centra Nederland (nu Winnock) dank ik voor de nieuwe inzichten die ik verwierf, de collega-onderzoekers van STEGA en AHORSE, de opleiders en collega-clinici in de OOR-ZON, de medewerkers van het Leerhuis en van het directoraat medische vervolgopleidingen en mijn secretaresse Manuela Heinrichs dank ik voor de samenwerking. Veel dank ben ik verschuldigd aan de Leden van het College van Bestuur van de Universiteit van Maastricht en van de Raad van Bestuur van het Maastricht Universitair Medisch Centrum, in het bijzonder aan de Decaan Prof. Albert Scherpbier en aan de leden van de Raad van Bestuur van het Atrium MC voor het in mij gestelde vertrouwen en de geboden mogelijkheden. En veel dank ben ik verschuldigd aan de studenten en assistenten die door hun coöperatieve instelling en goeie feedback de opleiding en de gezondheidszorg beter maken en mijn dagen extra kleur geven.

Tenslotte ben ik zeer dankbaar voor het gezin waarin ik ben opgegroeid, waarin alle goede Heyligers en Gunning genen de kans kregen zich te ontwikkelen en waarin ik geleerd heb te denken in de kansen en mogelijkheden die ík kreeg, voor iedereen. Mijn eigen gezin is de basis van mijn leven. Mijn vrouw Sacha voor wie ik geen geheimen heb, maar met wie ik alle geheimen kan delen, onze kinderen Boudewien en Djoeke, structuur en creativiteit, jullie zijn mijn 
universum, alleen door jullie sterren kan ik stralen. Wij zeggen het wel eens voor de grap, maar ik meen het: "Bedankt voor alles".

Ik heb gezegd.

\section{Referenties:}

Desmond A., Moore J. Darwin. Michael Joseph Ltd. London, the Pinguin Group, 1991.

Darwin C. De reis van de Beagle. Vertaling Frank van der Knoop, met een inleiding van David Quammen. National Geographic Society, 2009.

Junte J, Joris Laarman Lab, van wetenschap naar design. Zuiderlucht, maart 2013.

Heyligers SE, Translating Linguistic Relativity: Contexts of the Sapir - Whorf Hypothesis. Thesis for the MA Humanities at Middlesex University, London, 1998.

Norman G. Medical education: past, present and future. Prosp Med Educ 1:614, 2012.

Miller GE. The assessment of clinical skills,competence,performance. Academic Medicine (Supplement) 1990.

Sherbino J, Frank JR, editors. Educational design: a CanMEDS guide for the health professions. Ottawa: Royal College of Physicians and Surgeons; 2011.

Goede WM de, Heyligers IC. Het gebruik van checklists bij het aanleren van de competenties samenwerking en communicatie aan AIOS Orthopaedie.

Vereniging voor Medisch Onderwijs NVMO congres 2007, 14 - 16 november, Egmond aan Zee, the Netherlands.

Heyligers IC, Deguelle D, Koopmans R. Inloopspreekuur AIOS bevordert kwaliteit opleiding. Medisch Contact 63;8:341, 2008.

NRC Handelsblad, 17 mei 2013; 15. 
Senden R. Ambulatory gait analysis, clinical application and fall risk detection. Universitaire Pers Maastricht. 2013.

Boymans T, Heyligers IC, Grimm B. 3D-CT reference data for uncemented femoral implants in the very eldely. 56 th Orthopaedic Research Society (ORS), 2010, New Orleans, USA.

NRC Handelsblad, 20 en 21 april, 2013; 4.

De Groene Amsterdammer, 16 mei 2013; 18.

Sandel MJ. What Money Can't Buy. The moral limits of markets. Penguin Books, 2013.

www.oorzon.nl 